\title{
Review \\ Agroinfiltration Mediated Scalable Transient Gene Expression in Genome Edited Crop Plants
}

\author{
Maninder Kaur ${ }^{1}$, Pooja Manchanda ${ }^{1, *}$, Anu Kalia ${ }^{2}{ }^{\mathbb{D}}$, Farah K. Ahmed ${ }^{3}$, Eugenie Nepovimova ${ }^{4}$, \\ Kamil Kuca ${ }^{4,5, *(\mathbb{D})}$ and Kamel A. Abd-Elsalam ${ }^{6} \mathbb{B}$ \\ 1 School of Agricultural Biotechnology, College of Agriculture, Punjab Agricultural University, Ludhiana, \\ Punjab 141004, India; maninderkaur-coasab@pau.edu \\ 2 Electron Microscopy and Nanoscience Laboratory, Department of Soil Science, College of Agriculture, \\ Punjab Agricultural University, Ludhiana, Punjab 141004, India; kaliaanu@pau.edu \\ 3 Biotechnology English Program, Faculty of Agriculture, Cairo University, Giza 12613, Egypt; \\ farahkamel777@gmail.com \\ 4 Department of Chemistry, Faculty of Science, University of Hradec Kralove, \\ 50003 Hradec Kralove, Czech Republic; eugenie.nepovimova@uhk.cz \\ 5 Biomedical Research Center, University Hospital Hradec Kralove, 50005 Hradec Kralove, Czech Republic \\ 6 Plant Pathology Research Institute, Agricultural Research Center (ARC), 9-Gamaa St., Giza 12619, Egypt; \\ kamelabdelsalam@gmail.com \\ * Correspondence: poojamanchanda5@pau.edu (P.M.); kamil.kuca@uhk.cz (K.K.)
}

Citation: Kaur, M.; Manchanda, P.; Kalia, A.; Ahmed, F.K.; Nepovimova,

E.; Kuca, K.; Abd-Elsalam, K.A. Agroinfiltration Mediated Scalable Transient Gene Expression in Genome Edited Crop Plants. Int. J. Mol. Sci. 2021, 22, 10882. https://doi.org/ 10.3390/ijms221910882

Academic Editor: Setsuko Komatsu

Received: 7 September 2021

Accepted: 3 October 2021

Published: 8 October 2021

Publisher's Note: MDPI stays neutral with regard to jurisdictional claims in published maps and institutional affiliations.

Copyright: (c) 2021 by the authors. Licensee MDPI, Basel, Switzerland. This article is an open access article distributed under the terms and conditions of the Creative Commons Attribution (CC BY) license (https:/ / creativecommons.org/licenses/by/ $4.0 /)$.
Abstract: Agrobacterium-mediated transformation is one of the most commonly used genetic transformation method that involves transfer of foreign genes into target plants. Agroinfiltration, an Agrobacterium-based transient approach and the breakthrough discovery of CRISPR/Cas9 holds trending stature to perform targeted and efficient genome editing (GE). The predominant feature of agroinfiltration is the abolishment of Transfer-DNA (T-DNA) integration event to ensure fewer biosafety and regulatory issues besides showcasing the capability to perform transcription and translation efficiently, hence providing a large picture through pilot-scale experiment via transient approach. The direct delivery of recombinant agrobacteria through this approach carrying CRISPR/Cas cassette to knockout the expression of the target gene in the intercellular tissue spaces by physical or vacuum infiltration can simplify the targeted site modification. This review aims to provide information on Agrobacterium-mediated transformation and implementation of agroinfiltration with GE to widen the horizon of targeted genome editing before a stable genome editing approach. This will ease the screening of numerous functions of genes in different plant species with wider applicability in future.

Keywords: Agrobacterium; CRISPR/Cas9; genome editing; targeted site modification; transgene-free; transfer-DNA

\section{Introduction}

The CRISPR-Cas9 (Clustered Regularly Interspaced Short Palindromic repeat DNA Sequences- CRISPR associated), a Nobel prize-winning technology for the year 2020 pioneered by Emmanuelle Charpentier and Jennifer Doudna in 2012 proved to be an indispensable tool for editing genomes in the agricultural biotechnology field. Besides genome editing, this tool has been applied for studying gene regulation, epigenetic editing and chromatin engineering also [1]. The discoveries of meganucleases, zinc finger nucleases (ZFNs), Transcription Activator-Like Effector Nucleases (TALENs) followed by the breakthrough discovery of CRISPR-Cas9 have revolutionized the genome editing research. It involves targeted base editing of the genome through the use of Streptococcus pyogenes Cas 9 endonuclease and short guide RNA molecule (sgRNA) that revolutionized genetics and functional genomics $[2,3]$. The Cas9 endonuclease and sgRNA lead to the generation of 
DNA double-stranded breaks in the targeted genome sequences and ensure successful editing of plant genomes [4].

Plant biotechnology which involves the generation of genetic modifications of host cells through the introduction of foreign genes encased in a vector leads to the production of transgenic plants. These genetic modifications can be carried out through numerous methods namely indirect gene transfer methods like Agrobacterium-mediated, floral dip, agroinfiltration, and direct gene transfer methods like polyethylene glycol method (PEG)mediated method, particle bombardment (biolistics), microinjection, and electroporation (Figure 1). These serve as a key for the development of genetically engineered plants with the trait of interest in a limited time that circumvents the conventional plant breeding approaches. In all the above-mentioned methods, widely acceptable genetic transformation method includes indirect transfer using Agrobacterium [5]. It is one of the most preferred techniques for the generation of genetically modified plants [6] as Agrobacterium-a natural genetic engineer, can deliver the desired gene of interest naturally due to its innate ability to transfer T-DNA. Scientists have explored their vision for using the genome editing process in conjugation with the Agrobacterium-mediated process through the use of Cas9 and sgRNA in the T-DNA to perform specific base editing.

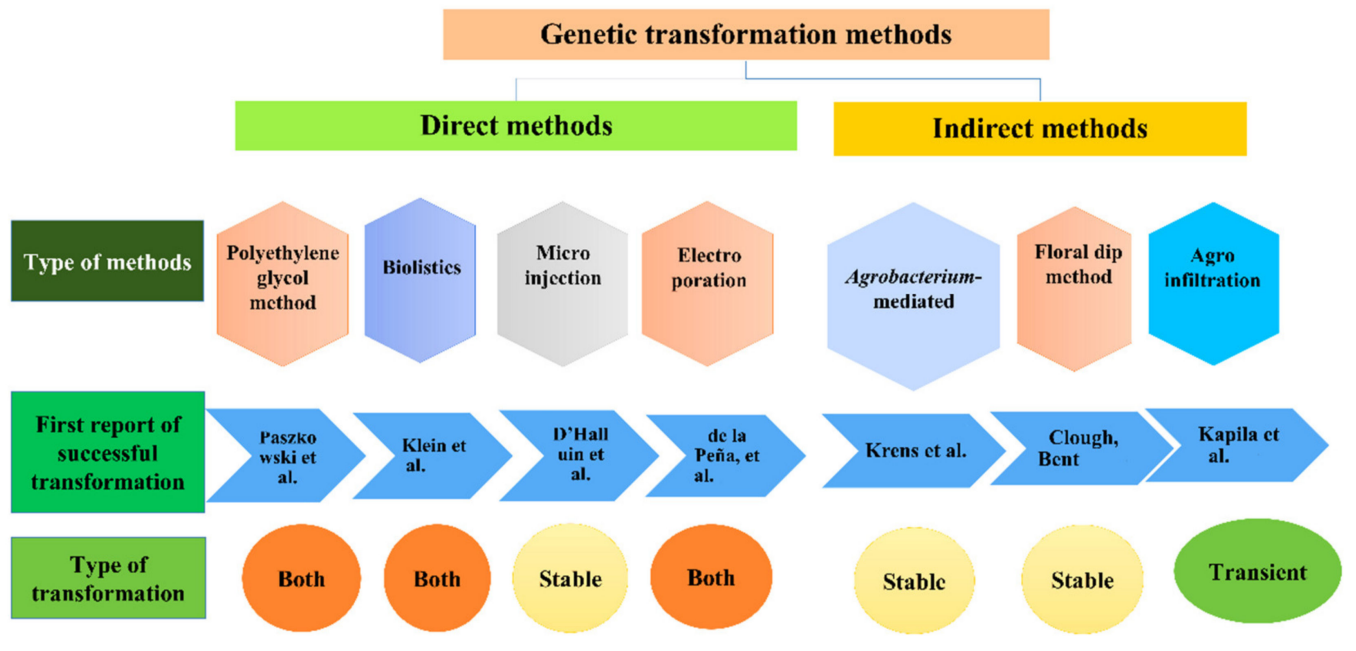

Figure 1. Genetic transformation methods in plants [7-13].

Recently, Sandhya et al. [14] reviewed numerous CRISPR/Cas9 based delivery methods such as Agrobacterium-mediated, biolistics, PEG-mediated, and floral dip or pollen-tube pathway method. But all these methods require sophisticated strategies for the selection of desired transformants possessing novel characteristics. Moreover, numerous confirmation protocols are required to ascertain the successful transfer of the gene and proper functioning of the gene of interest in the host plant [15]. The Agrobacterium-based floral dip method undergoes a stable transformation that targets the germinal cells while Agrobacterium-based transient approach i.e., agroinfiltration target somatic cells, hence not transferred to the next generation. The genetic engineering technology mostly suffers from major limitations like low transformation efficiency, high time requirements, and event of insertion of foreign DNA in the host plant leading to stable transformation [16].

Keeping in view the generation of stable transformation through Agrobacterium-based technique that involves tissue culture, we simply focus on Agrobacterium-based transient agroinfiltration approach which does not involve time-consuming tissue culturing step [17]. As the CRISPR/Cas9 DNA editing still has regulatory and biosafety concerns [18,19], therefore, transient expression through agroinfiltration-based genome editing holds promise in the present era that will overcome the legislation concerns due to its temporary expression for a limited time $\sim$ within 3 days [20]. 


\section{Genome Editing Methods}

The CRISPR/Cas9 system has been successfully applied in various plant species for site-specific base modifications through various genetic transformation methods with varying editing efficiency. It has been observed that the editing efficiency of $9.6 \%, 18.4 \%$, and $31.9 \%$ can be obtained in the edited lines depending on the Agrobacterium-mediated transformation, ribonucleoprotein complexes, and transient expression in protoplasts respectively [21]. Another advancement of the CRISPR/Cas9 genome editing, the Transiently Expressed CRISPR/Cas DNA (TECCDNA) is a simple and efficient genome-editing approach in which mutant plants are regenerated after transient expression of CRISPR/Cas9 DNA [22]. The CRISPR/Cas9 DNA (plasmid constructs) or RNA (in vitro synthesized transcripts) can be delivered through biolistic technique. The circumvention of lengthy and labour-intensive herbicide selection steps on a medium supplemented with antibiotic was escaped concluding that the foreign DNA does not get integrated into the genome. Generally, the plant genome editing tools require additional cycles of plant regeneration under antibiotic selection medium but TECCDNA approach excluded the addition of herbicide or antibiotics addition to the medium meant for the selection of transformed plants. After biolistic delivery of TECCDNA, embryos were transferred to callus induction, regeneration, and rooting medium that generated a large number of $\mathrm{T}_{0}$ seedlings about 1 week later provided no selective agents were used during the tissue culture process. After TECCDNA, CRISPR-Cas ribonucleoprotein (RNP) served as a simple, convincing, and promising tool for precision plant breeding [23] (Figure 2). This technique has been used for targeted genomic modifications without causing any genomic disturbances or off-target effects [24]. Contrastingly, agroinfiltration involves the direct introduction of a foreign gene in the intercellular [7] and extracellular [25] leaf spaces thereby circumventing the requirement of expensive biolistic equipment for both TECCDNA and CRISPR-Cas RNP approaches. The use of lengthy procedures and sophisticated/ specialized equipment can be avoided through the implementation of the agroinfiltration approach.
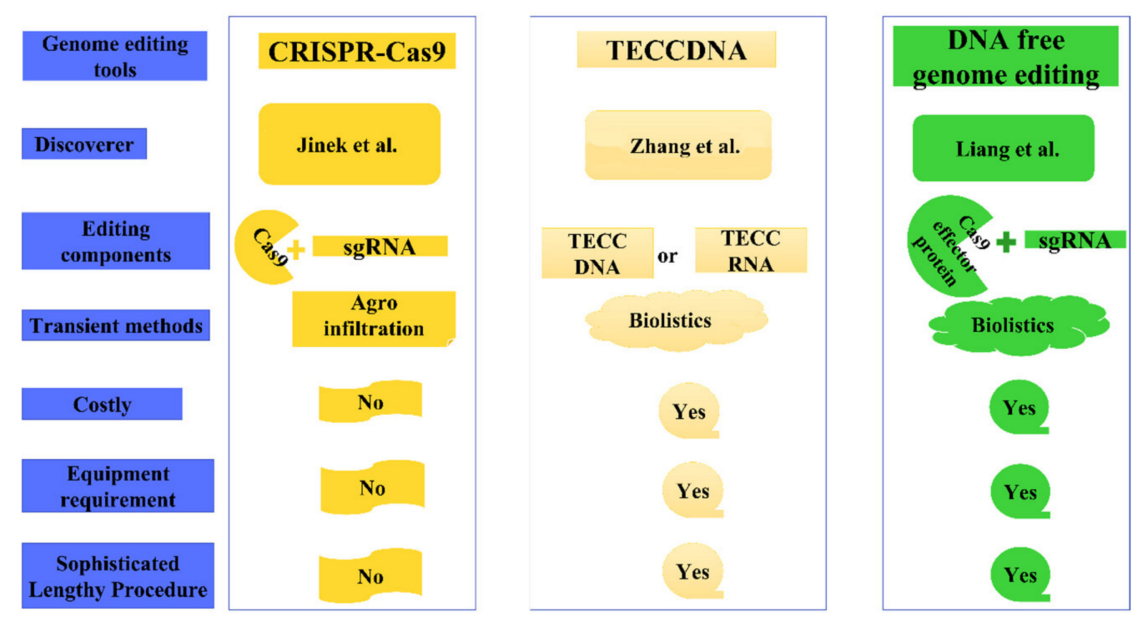

Figure 2. Genetic transformation methods in plants [26-28].

Specific reviews [29-33] are available on transient gene expression in different host organisms. Sheludko [29] reviewed the biological characteristics of the transient expression process and application for recombinant protein production. Tyurin et al. [33] also reviewed the main and critical steps involved in various methods for transient gene expression in plants. Another recent review by Zlobin et al. [4] elaborated the utilization of Agrobacteriumbased floral dip transformation for genome editing. However, the floral dip transformation method falls short for targeting a single gene due to several specific problems such as nonreproducibility of the process, generation of false-positive results, and low transformation efficiency. Therefore, the agroinfiltration transient approach has several applications in genome editing which have numerous advantages over stable transformation. The primary 
objective of this compilation is to pursue the plant researcher's focus on the transient approach of agroinfiltration-based genome editing for site-specific modification research. Therefore, the first comprehensive compilation on the use of agroinfiltration in CRISPRCas9 mediated genome editing and implementation of agroinfiltration-based genome editing method(s) in plants.

\section{Priority towards Agrobacterium-Based Genetic Transformation}

Agrobacterium tumefaciens holds a prominent stature in plant biotechnology since its discovery in the late 18th century till date. Since, the first genetically modified plants using Agrobacterium-mediated genetic transformation process in the year 1983, plant genetic transformation has become an indispensable tool for plant biology, crop improvement and commercial farming interventions [34]. It generally refers to the process of alteration of genetic constituents in the host plant through the introduction of the gene of interest through genetic engineering to achieve desired gene expression [35]. Agrobacterium harboring the tumor-inducing (Ti) plasmid although responsible for causing crown gall, cane gall, and hairy root disease yet it has become the most popular plant transformation tool that has the requirement of two genetic components i.e T-DNA and virulence region located on the bacterial Ti-plasmid. The plant researchers developed the recombinant Agrobacterium strains that do not lead to tumor formation but possess the capability to transfer gene(s) of interest to pursue plant transformation [36]. Its success is based on numerous genetic transformation methods that exhibit few advantages and disadvantages. The biggest advantage includes the utilization of genetic transformation methods with the advent of genetic engineering which evades time-consuming techniques for the transfer of desired traits through traditional plant breeding techniques.

The indirect gene transfer involves the introduction of foreign DNA in the host plant utilizing biological vectors (Agrobacterium). While direct gene transfer techniques involve direct delivery of foreign DNA in the plant genome through various physical or chemical agents such as particle bombardment [8,37], microinjection [38], PEGylation or calcium phosphate mediated protoplast transformation [39,40], electroporation [41,42], and silicon carbide whisker-enabled transformation [43] (Figure 1).

The major advantage of the Agrobacterium-mediated transformation process is a lowcost transfer of a single copy of the gene of interest omitting out the problem of gene silencing [44-51]. Hwang et al. [52] reviewed the advantages of the Agrobacterium method comprehensively. They have presented it as the most frequently used and most popular method of genetic engineering in the present era. Also, its considerable and ever-expanding contribution for the elucidation of fundamental mechanisms to study gene regulation or protein function in transgenic plants in basic biology research is noteworthy [53].

The indirect transfer of foreign DNA through A. tumifaciens utilizes the innate ability of Agrobacterium to transfer intact T-DNA through Type 4 secretion system [52,54,55]. It favours trans-kingdom DNA transfer [56].

Earlier, Agrobacterium-mediated transformation process was possible only in dicots due to the release of acetosyringone (phenolic compound) but nowadays, this method can be applied broadly in the cereal species, gymnosperms, yeast, and many filamentous fungi $[57,58]$. A. tumefaciens can transform non-host also including fungi, algae, sea urchin embryos, human cells, and the gram-positive bacterium Streptomyces lividans [59-70]. The wide host range of Agrobacterium equips it to be effectively utilized for the generation of transgenic plants [71]. Agrobacterium-mediated genetic transformation is applicable to plant species, variants, and cultivars for plant genome modifications [72-74]. Moreover, A. tumefaciens can be equally utilized for both transient and stable transformation methods in plants.

Keeping in view the advantage of this phytopathogen, the complex Agrobacteriumplant interactions have been reviewed extensively [31,75-80]. Recently, Nonaka et al. [81] have developed the Super-Agrobacterium ver. 4 that has major application in basic plant science research. It has been reported that Super-Agrobacterium ver. 3 was effective in the agro-infiltration method $[82,83]$. 


\section{Types of Agrobacterium-Based Genetic Transformation}

The Agrobacterium-based genetic transformation undergo two specific mechanisms; stable (T-DNA integration in the genome stably inherited) [84-87] and transient transformation (absence of T-DNA integration in the genome still capable to perform transcription and translation) [52,88-94]. The expression of T-DNA carrying the gene of interest occur in either transient or stable manner was demonstrated by Krenek et al. [30], Janssen and Gardner [95]. Both stable and transient transformation methods can be utilized in genome editing [96], to study the gene and protein function [97,98], molecular processes [99] and are applicable to numerous plant species [100]. Heenatigala et al. [99] have developed efficient protocols for stable and transient gene transformation for Wolffia globosa using Agrobacterium that has application in a wide range of scientific and commercial processes. Stable genetic transformation process is more appropriate to study long-term analysis of gene function or for long-term production of specific compounds but has the requirement of several months. However, if the target is to introduce a gene of interest in a short period to produce desired protein products, the preferred method is transient transformation [99]. Hence, transient transformation is a preferred method to study short-term gene expression analysis [101].

\section{Stable Genetic Transformation}

The transfer of T-DNA through Agrobacterium leading to the inheritance in the next generation referred as stable transformation. Generally, this method confers the gene transfer through Agrobacterium via two means; co-cultivation method (including tissue culture technology) and floral dip method (devoid of tissue culture). The co-cultivation method using Agrobacterium suspension containing desired gene of interest involves culturing the explant. Although it leads to the formation of stable transformants yet it suffers from several disadvantages such as non-uniform transformants can be obtained due to genetic and epigenetic changes that occur during repeated culturing. The induction of callus during tissue culture is a cumbersome approach leading to the generation of undesirable somaclonal variations thus regeneration protocols have not been developed for all plant species.

The widely adapted Agrobacterium-mediated stable gene transfer method is the floral dip method. The floral dip method avoids the subsequent tissue culturing steps that may lead to generation of somaclonal variants such that desired transformants can be obtained within a short time period as compared to the co-cultivation method [52].

\section{Transient (Temporary) Genetic Transformation}

The temporary integration of the exogenous DNA in the plant progeny is the basis of transient transformation of plant tissues [102]. Agrobacterium-mediated genetic transformation involves transfection of millions of plant cells by T-DNA in a short period. It allows only a short-term (transient) expression of the gene constructs in a plant cell. The transient approach holds the fact that disarmed Agrobacterium strains lead to modification of nonreproductive or somatic tissue which is not inherited and hence transient in nature [103]. It has been reported that heritable mutations adhering to Mendel's law only have the potential to transfer to the next generations [104] but this is not the case in agroinfiltration because transgenes are transiently expressed in somatic cells of plant tissues and not germ cells hence not heritable. Transient gene expression has been demonstrated to produce large amounts of recombinant proteins in a very short time of few days $[105,106]$. The somatic cells in the zone of agroinfiltration have the potential to express the transgenes under the control of the constitutive CaMV-35S promoter within 3-5 days after agroinfiltration. A transient expression is an approach for the verification of transformation construct activity and the validation of the formation of small amounts of recombinant protein. Potrykus [107] reviewed the most widely used Agrobacterium infiltration method utilized for transient transformation in Nicotiana benthamiana. The generation of simple insertion events for the T-DNA marked by the border (left and right) sequences in a binary vector is the hallmark of generating transgenics with a reduced frequency of transgene 
silencing [108]. Zheng et al. [109] have developed the conventional Agrobacterium-mediated transient gene expression system in which the seedlings and plantlets were co-cultivated with Murashige and Skoog medium containing Agrobacterium for several days exhibiting transient expression of the $\beta$-glucuronidase (GUS) gene. Further, it is a shorter and efficient way that can help reduce the time required for the development of rice transgenics [110].

Fischer et al. [111] have also reported that transient gene expression is a convenient method as compared to time-consuming stable transformation methods for the production of recombinant proteins. It has been reported that $100 \%$ transient transformation efficiency can be achieved in Nicotiana benthamiana and lettuce [112]. The biggest advantage of plant transient transformation is the gene expression for a short time, in which the target gene can express within $12 \mathrm{~h}$ and high expression could be attained within $2 \sim 4$ days in the plant cells [113]. The non-integrated T-DNA copies remain transiently present in the nucleus that can transcribe and translate, leading to T-DNA transient gene expression. The transient genetic transformation can unveil the complex functional genomics in conifer species [114] and medicinal plants [115].

Li et al. [92] have developed a novel transient assay Fast Agro-mediated Seedling transformation (FAST) in the year 2009 which was based on co-cultivation of Arabidopsis seedlings with Agrobacterium tumefaciens in the presence of a Silwet L-77 surfactant. They have successfully expressed the constructs driven by different promoters in cotyledons but not roots of Arabidopsis seedlings in diverse genetic backgrounds through this approach. Another method AGROBEST (Agrobacterium-mediated Enhanced Seedling Transformation) has also been developed during the year 2014 by Wu et al. [94] to obtain high transient transformation efficiency in whole seedlings. Presently Agrobacterium-based transient transformation is a safe, high-level, and rapid transient transgene expression method [95,116-118]. Moreover, agroinfiltration is a promising technology for in planta transient expression of high-value recombinant proteins $[119,120]$. Also, A. tumefaciens based transient gene expression tends to affect plant signal transduction that could be used for studying various regulatory processes and defense mechanisms in the plant system [121].

\section{Stable vs. Transient Genetic Transformation}

The transient genetic transformation exhibits upto $21.8 \%$ high transformation efficiency as compared to $0.14 \%$ stable genetic transformation efficiency [99]. Stable transformation being labour intensive process that takes even 15 months [122] or even more for the production of transformed plants. On the other hand, transient transformation is a rapid method with a high expression level. The transient expression holds promise before implementing the tedious and time-consuming stable expression methods $[30,94,123]$. The transient transformation has several advantages over stable transformation as mentioned below:

(i) Exemption of tissue culture [33]

(ii) Temporary expression [52]

(iii) T-DNA position effect elimination [33]

(iv) Simple, quick, economical, and effective [109]

(v) The transient transformation frequency was at least 1000-fold greater than that of stable transformation $[29,95]$

(vi) Transient transformation is often versatile, quick, and efficient as compared to stable transformation [99].

\section{Agroinfiltration}

The transient expression methods include transfection of protoplasts using PEGmediated or electroporation [124], biolistics [125], and agroinfiltration [126], but agroinfiltration is a simple and effective method for transfer of the gene of interest in the host cell [118]. It involves direct delivery of recombinant agrobacteria carrying the gene of interest in the extracellular leaf spaces by physical or vacuum infiltration [25]. Agroinfiltration led to a transfer of single-stranded T-DNA from Agrobacterium to the plant cells which is 
trafficked through chaperones to the nucleus. During integration, a small percentage of T-DNA is integrated into the host chromosomes that lead to the development of stable transformation [36]. On the other hand, part of T-DNAs that do not integrate into chromosomes results in the high production of short-lived recombinant protein production [127]. The host factors (karyopherin $\alpha$ and VIP1), bacterial factors (VirD2, VirE2, and VirE3), and plant factor KU80 play a vital role in T-DNA integration in Agrobacterium-based genetic transformation methods [6]. Moreover, this method applies to leaf tissue as well as other plant organs, like fruits and berries and recalcitrant plant species $[33,128]$. Agroinfiltration has high transformation efficiency, high scalability, and ease of multiple transient expression assays with multiple transgenic vectors and multiple $\mathrm{R}$ genes carrying the gene of interest on a single leaf $[129,130]$. The transient expression of two resistance genes $C f-9$ and $C f-4$ has been observed in tomato plants through agroinfiltration approach in tobacco. It has also been observed that co-expression of $R$ gene with the corresponding Avr gene trigger host-defence responses in a hypersensitive response in Nicotiana tabacum. It resulted in the formation of the necrotic sector through the expression of both genes in the overlapping region that led to the transient production of $\mathrm{R}$ and Avr proteins in the infiltrated leaf area through agroinfiltration [131]. Kapila et al. [7] have first worked on the intact petunia leaves for the expression of heterologous proteins through the infiltration of A. tumefaciens suspensions of harbouring a binary vector into leaf interstitial spaces. The gene transfer through agroinfiltration enabled the transfer of T-DNA in all cell layers of the leaf including intercellular spaces in the upper epidermis, lower epidermis, and palisade parenchyma, spongy parenchyma, and interstitial cell layers. Li et al. [92] have developed the transient agro-infiltration method for rapid production of recombinant protein, an attribute fundamental for functional genomics studies. The process of Agroinfiltration is temporary as it remains in the in vivo system for a limited period [132], therefore, there occurs no T-DNA integration into the plant genome $[133,134]$. The implementation of transient genetic transformation in the research studies will serve as a pilot experiment before following stable transformation which will provide information about the knock-out effect of the gene in question. It could be used in replacement of the in vitro transcription and cleavage assay of sgRNA and Cas9 protein of protoplast transfection method. It has been reported that Agrobacterium-based transient agroinfiltration can achieve success within 3 days without the need for any cumbersome procedures and equipment. Moreover, Agrobacterium-based transient approach agroinfiltration is the one that saves time, labour will lead to the temporary transformation which will make genome editing "safer technology". A synonym term agroinoculation implies the use of a virus-based vector while agroinfiltration is based on the implementation of binary vector marks the difference between both approaches [135]. In comparison with the plant breeding based back crosses approach that has the potential to remove the CRISPR-Cas9 vector insertion and retain only the beneficial gene-edited alleles but agroinfiltration is an efficient approach that can be performed as a preliminary screening technique for somatic or germinal cells and later the stable transformation technique can be followed.

The transient protein production in the cytoplasm due to the absence of insertion of genes into the crop genome will have an exemption from transgenic regulation and hence greater public acceptance [131]. Agroinfiltration results in the direct creation of markerfree tobacco plants [136]. It is the method that results in the rapid functional analysis of transgenes directly [137]. The molecular and functional analysis can also be achieved through agroinfiltration [138]. The genetic background and the tissue culture conditions are the important measures for a successful agroinfiltration experiment [139].

\section{Methods of Agroinfiltration}

Agroinfiltration can be carried out through numerous methods like syringe infiltration, vacuum infiltration, hydrogen peroxide-based agroinfiltration, special agroinfiltration method, leaf disc vacuum infiltration, spray-based agroinfiltration, and detached leaf-based infiltration approach which will be briefly summarised here. Generally, agroinfiltration is 
carried out using two methods; syringe and vacuum infiltration applicable for a variety of plant species (Tables 1-3). Among these methods, vacuum infiltration requires specialized equipment but exhibits improved transformation potential or yield [98]. An advanced modified version of the vacuum infiltration technology namely leaf disc vacuum infiltration has also been developed that involves pulling off the syringe plunger for the creation of a small vacuum in the syringe [140]. Likewise, Xu et al. [141] have developed a special agroinfiltration method to attain gene expression within 5 days. This method involved the injection of the gene of interest into the interfaces between the adaxial epidermis and mesophyll using a plastic syringe with a needle. This leads to the formation of an agroinfiltration bubble (approximately $1 \mathrm{~cm}^{2}$ area) with a high ratio of agrobacteria carrying gene of interest to be infiltrated in the epidermal cells.

Shin and Park [142] have developed another agroinfiltration method namely hydrogen peroxide-based agroinfiltration. The use of this abrasive chemical induces wounds in the treated tissue which results in the improvement in the transformation efficiency in Chinese cabbage. A novel spray-based agroinfiltration is the technology that is applicable without the need of a vacuum chamber [143]. The detached leaf-based infiltration approach is also developed to overcome the necrosis, photo-bleaching, browning, and senescence cell death problem in intact leaves [144].

\section{Factors Affecting Agroinfiltration}

The success of agroinfiltration depends on numerous factors that need to be optimized to increase the transformation efficiency $[97,140]$. These factors influence the transfer of T-DNA from Agrobacterium to plant cells [145] and include plant genotype, type of explant, Agrobacterium strain, cell density in the inoculation medium, inoculation conditions, and co-culture. A comprehensive detail about these factors as discussed in previous reports has been presented in Table 1. Apart from these factors, numerous physical and molecular factors need to be considered during Agrobacterium-mediated transformation. The physical factors include ambient and leaf temperature, light source, $\mathrm{pH}$, osmotic conditions, explant type, bacterial strain, density, and co-cultivation time that may affect the Agrobacteriumbased transformation [146-148]. The infiltration time for $30 \mathrm{~min}$ has been observed to improve the transformation in Medicago leaves while less than 25 min was considered to be best for Trifolium leaves [149]. The surfactants such as Silwet L-77 or dark treatment after infiltration can improve the transformation efficiency during transient transformation [25]. The effects of the infiltration method, Agrobacterium strain, and age of the donor plant are the critical factors in the transient transformation studies [150]. Secondly, molecular factor involving foreign gene transfer followed by transgene expression may be altered by the inherent host plant mechanism of post-transcriptional gene silencing [151]. It has been observed that gene silencing results in the loss of protein expression so the co-expression of gene silencing inhibitor (e.g., p19 protein from tomato bushy stunt virus, NS1 protein from human influenza A virus and P1/HC-Pro protein of Tobacco etch potyvirus) can lead to 50 fold enhancement in the expression of the candidate protein through agroinfiltration process $[152,153]$. 
Table 1. Optimization of various parameters for agroinfiltration in plants.

\begin{tabular}{|c|c|c|c|c|c|c|c|c|c|c|c|}
\hline Plant & Family & $\begin{array}{c}\text { Cultivar/ } \\
\text { Genotype (s) }\end{array}$ & Target Gene & Tissue & Method & $\begin{array}{c}\text { Agrobacterium } \\
\text { Strain (s) }\end{array}$ & Binary Vector (s) & $\begin{array}{l}\text { Optimization for } \\
\text { Agroinfiltration }\end{array}$ & $\begin{array}{l}\text { Detection } \\
\text { Methods }\end{array}$ & Remarks & Reference \\
\hline \multicolumn{12}{|c|}{ Model Plants } \\
\hline $\begin{array}{l}\text { Arabidopsis } \\
\text { thaliana (Ara- } \\
\text { bidopsis) }\end{array}$ & Brassicaceae & $\begin{array}{l}\text { Columbia } \\
\text { (Col-0) ecotype }\end{array}$ & GUS & Leaf & $\begin{array}{c}\text { Syringe } \\
\text { (needleless) }\end{array}$ & $\begin{array}{l}\text { LBA4404, } \\
\text { C58C1, } \\
\text { GV3101, } \\
\text { EHA105 and } \\
\text { AGL-1 }\end{array}$ & pCAMBIA1304 & $\begin{array}{l}0.01 \% \text { Triton X-100 } \\
\text { or } 0.01 \% \text { Tween-20 } \\
\text { LAB4404-Best } \\
\text { Agrobacterium strain }\end{array}$ & GUS staining & $\begin{array}{l}\text { Incubation of the } \\
\text { infiltrated plants } \\
\text { under short day } \\
\text { conditions at } \\
\text { high relative } \\
\text { humidity } \\
\text { maximize the } \\
\text { gene expression }\end{array}$ & [91] \\
\hline $\begin{array}{l}\text { Cucumis } \\
\text { melo L. } \\
\text { (Melon) }\end{array}$ & Cucurbitaceae & - & $\begin{array}{l}\text { Nattokinase } \\
\text { (NK) }\end{array}$ & Fruit & $\begin{array}{l}\text { Syringe } \\
\text { (needle) }\end{array}$ & LBA4404 & $\begin{array}{c}\text { pPZP35S, } \\
\text { pPZP35SN, } \\
\text { pPZP35SNi, } \\
\text { pPZPE8, pPZPE8N } \\
\text { and pPZPE8Ni }\end{array}$ & $\begin{array}{l}\text { Acetosyringone } \\
0.2 \mathrm{~mm} \text { and } \\
\text { Codon-optimized } \\
\text { synthetic NK gene }\end{array}$ & $\begin{array}{l}\text { Quantitative } \\
\text { Real Time PCR } \\
\text { (qRT-PCR) } \\
\text { analysis and } \\
\text { fibrinolytic } \\
\text { activity }\end{array}$ & $\begin{array}{l}\text { High expression } \\
\text { of recombinant } \\
\text { NK gene }\end{array}$ & [154] \\
\hline $\begin{array}{l}\text { Glycine max } \\
\text { (Soybean) }\end{array}$ & Fabaceae & $\begin{array}{l}\text { Williams 82, } \\
\text { Jack, JackX, } \\
\text { 'Peking', } \\
\text { L77-1863 and } \\
\text { Williams }\end{array}$ & GUS & $\begin{array}{l}\text { Leaf and } \\
\text { seedlings }\end{array}$ & $\begin{array}{c}\text { Syringe } \\
\text { (needleless) } \\
\text { and vacuum }\end{array}$ & $\begin{array}{c}\text { A281 } \\
\text { EHA105 } \\
\text { LBA4404 } \\
\text { Ach5 and J2 }\end{array}$ & pCambia1305.1 & $\begin{array}{l}\text { Infiltration buffer } \\
\quad(10 \mathrm{mM} \\
\text { 2-(N-morpholino) } \\
\text { ethanesulfonic acid } \\
\text { sodium salt, } 10 \mathrm{mM} \\
\mathrm{MgCl}_{2}, 100 \mu \mathrm{M} \\
\text { acetosyringone) } \\
\text { with dithiothreitol } \\
\text { and } 30 \text { s sonication }\end{array}$ & GUS assay & $\begin{array}{l}\text { Increase in the } \\
\text { agroinfiltration- } \\
\text { mediated GUS } \\
\text { expression }\end{array}$ & [155] \\
\hline \multirow[b]{2}{*}{$\begin{array}{l}\text { Nicotiana } \\
\text { benthamiana } \\
\text { (Tobacco) }\end{array}$} & \multirow[b]{2}{*}{ Solanaceae } & - & GUS & Leaf & $\begin{array}{c}\text { Syringe } \\
\text { (needleless) }\end{array}$ & EHA105 & pCAMBIA1301 & $\begin{array}{c}20 \mu \mathrm{M} \text { azacytidine, } \\
0.56 \mathrm{mM} \text { ascorbate } \\
\text { and } 0.03 \%(v / v) \\
\text { Tween-20 }\end{array}$ & qRT-PCR & $\begin{array}{l}\text { At about 6-fold } \\
\text { higher transient } \\
\text { gene expression }\end{array}$ & [98] \\
\hline & & - & GUS & Leaf & Syringe & $\begin{array}{l}\text { AGL1, C58C1 } \\
\text { and LBA4404 }\end{array}$ & pEAQ-GSN & $\begin{array}{c}\text { Acetosyringone } \\
(500 \mu \mathrm{M}), \\
\text { Lipoic acid }(5 \mu \mathrm{M}), \\
\text { Pluronic F-68 } \\
(0.002 \%) \text { and } \\
37^{\circ} \mathrm{C} \text { heat shock }\end{array}$ & $\begin{array}{c}\text { GUS assay, } \\
\text { Enzyme-linked } \\
\text { immunoassay } \\
\text { (ELISA) and } \\
\text { Polyacry- } \\
\text { lamide gel } \\
\text { electrophoresis } \\
\text { (PAGE) analysis }\end{array}$ & $\begin{array}{c}\text { Around 3.5-fold } \\
\text { higher levels of } \\
\text { absolute GUS } \\
\text { protein } \\
\text { compared to the } \\
\text { pEAQ-HT } \\
\text { deconstructed } \\
\text { virus vector } \\
\text { platform }\end{array}$ & [118] \\
\hline
\end{tabular}


Table 1. Cont.

\begin{tabular}{|c|c|c|c|c|c|c|c|c|c|c|c|}
\hline Plant & Family & $\begin{array}{c}\text { Cultivar/ } \\
\text { Genotype (s) }\end{array}$ & Target Gene & Tissue & Method & $\begin{array}{l}\text { Agrobacterium } \\
\text { Strain (s) }\end{array}$ & Binary Vector (s) & $\begin{array}{l}\text { Optimization for } \\
\text { Agroinfiltration }\end{array}$ & $\begin{array}{l}\text { Detection } \\
\text { Methods }\end{array}$ & Remarks & Reference \\
\hline & & Wild-type & $\begin{array}{c}\text { Green } \\
\text { fluorescent } \\
\text { protein }(G F P)\end{array}$ & Leaf & $\begin{array}{c}\text { Syringe } \\
\text { (needleless) }\end{array}$ & $\begin{array}{l}\text { EHA105, } \\
\text { LBA4404, } \\
\text { AGL0 and } \\
\text { AGL1 }\end{array}$ & pCAMBIA(gfp)1302 & $\begin{array}{c}\text { Best } \text { Agrobacterium } \\
\text { strain-AGL0 and } \\
\text { EHA105, } \\
\text { acetosyringone } \\
450-600 \mu \mathrm{M}, \text { viral } \\
\text { protein HC-Pro, } \\
\text { Leaf ageing }\end{array}$ & GFP imaging & $\begin{array}{l}\text { High gene } \\
\text { expression was } \\
\text { observed in the } \\
\text { youngest leaf }\end{array}$ & [156] \\
\hline & & $\begin{array}{l}\text { Wild type non- } \\
\text { transgenic } \\
\text { plants }\end{array}$ & $\begin{array}{c}\text { Anthrax } \\
\text { receptor decoy } \\
\text { protein (im- } \\
\text { munoadhesin) } \\
\text { and } C M G 2-F c\end{array}$ & $\begin{array}{l}\text { Whole } \\
\text { plants and } \\
\text { detached } \\
\text { Leaf }\end{array}$ & Vacuum & - & pBIN and pCB302 & $\begin{array}{l}\text { Number of viral } \\
\text { suppressors of } \\
\text { post-transcriptional } \\
\text { gene silencing } \\
\text { constructs: p1, p10, } \\
\text { p19, p21, p24, p25, } \\
\text { p38, 2b, and HCPro }\end{array}$ & $\begin{array}{l}\text { ELISA, Bradford } \\
\text { assay and } \\
\text { Western Blotting }\end{array}$ & $\begin{array}{c}\text { p1 exhibit } \\
\text { maximum gene } \\
\text { expression } \\
\text { contributing } \\
\text { towards post } \\
\text { transcriptional } \\
\text { gene silencing }\end{array}$ & [157] \\
\hline & & - & $A v e 1$ and $V e 1$ & Leaf & Syringe & GV3101 & $\begin{array}{c}\text { Gateway- } \\
\text { compatible binary } \\
\text { vectors }\end{array}$ & $\begin{array}{l}\text { Gateway- } \\
\text { compatible binary } \\
\text { vectors improve } \\
\text { agroinfiltration } \\
\text { efficiency }\end{array}$ & $\begin{array}{l}\text { Polymerase } \\
\text { Chain Reaction } \\
\text { (PCR) }\end{array}$ & $\begin{array}{l}\text { Ve1-mediated } \\
\text { resistance } \\
\text { against } \\
\text { verticillium }\end{array}$ & [158] \\
\hline & & $\begin{array}{l}\text { Transgenic } \\
\text { plants }\end{array}$ & $\begin{array}{c}A C 1, A C 2, A C 4 \\
\text { from } D N A-A \\
\text { and } B C 1 \text { from } \\
D N A-B \text { of } \\
\text { African } \\
\text { cassava mosaic } \\
\text { virus (ACMV) }\end{array}$ & Leaf & $\begin{array}{c}\text { Syringe } \\
\text { (needleless) }\end{array}$ & GV3101 & $\begin{array}{l}\text { RNA interference } \\
\text { constructs }\end{array}$ & $\begin{array}{c}\text { ACMV- } \\
\text { Cameroon:DO2:1998 } \\
\text { transient } \\
\text { protection assay }\end{array}$ & $\begin{array}{l}\text { Electrophoresis, } \\
\text { southern and } \\
\text { northern } \\
\text { hybridizations }\end{array}$ & $\begin{array}{l}\text { Systemic } \\
\text { movement of the } \\
\text { silencing signal }\end{array}$ & [160] \\
\hline & & - & $\begin{array}{l}\text { Hemagglutinin } \\
\text { ectodomain } \\
\text { derived from } \\
\text { influenza A } \\
\text { virus strain A }\end{array}$ & $\begin{array}{l}\text { Detached } \\
\text { leaf }\end{array}$ & Vacuum & GV3101 & pMP90 & $\begin{array}{l}\text { Variation in the } \\
\text { duration of water } \\
\text { removal treatment } \\
\text { from } 0.7 \text { to } 4.4 \mathrm{~h}\end{array}$ & $\begin{array}{l}\text { Sodium dodecyl } \\
\text { sulfate polyacry- } \\
\text { lamide gel } \\
\text { electrophoresis } \\
\text { (SDS-PAGE) }\end{array}$ & $\begin{array}{l}\text { Improvement in } \\
\text { recombinant } \\
\text { hemagglu- } \\
\text { tinin yield }\end{array}$ & [161] \\
\hline
\end{tabular}


Table 1. Cont.

\begin{tabular}{|c|c|c|c|c|c|c|c|c|c|c|c|}
\hline Plant & Family & $\begin{array}{c}\text { Cultivar/ } \\
\text { Genotype (s) }\end{array}$ & Target Gene & Tissue & Method & $\begin{array}{l}\text { Agrobacterium } \\
\text { Strain (s) }\end{array}$ & Binary Vector (s) & $\begin{array}{l}\text { Optimization for } \\
\text { Agroinfiltration }\end{array}$ & $\begin{array}{l}\text { Detection } \\
\text { Methods }\end{array}$ & Remarks & Reference \\
\hline & & - & $\begin{array}{l}\text { Human } \\
\text { epidermal } \\
\text { growth factor }\end{array}$ & Leaf & $\begin{array}{c}\text { Syringe } \\
\text { (needleless) }\end{array}$ & GV3101 & pBYR2e-hEGF & $\begin{array}{c}\text { Expression vector } \\
\text { carrying different } \\
\text { hEGF constructs, } \\
\text { Agrobacterium cell } \\
\text { density }(0.2,0.4,0.6, \\
\text { and } 0.8) \text { at OD600 }\end{array}$ & ELISA & $\begin{array}{l}\text { Production of } \\
\text { recombinant } \\
\text { hEGF protein }\end{array}$ & [162] \\
\hline & & - & $\begin{array}{l}\text { GFP, DsRed } \\
\text { fluorescent } \\
\text { protein, Yellow } \\
\text { fluorescent } \\
\text { protein }(Y F P) \\
\text { and Cyan } \\
\text { Fluorescent } \\
\text { Protein }(C F P)\end{array}$ & Leaf & $\begin{array}{c}\text { Syringe } \\
\text { (needleless) }\end{array}$ & EHA105 & $\begin{array}{l}\text { pBYKEAM or } \\
\text { pBYKEAM2 }\end{array}$ & $\begin{array}{l}\text { Plant expression } \\
\text { vectors }\end{array}$ & $\begin{array}{c}\text { SDS-PAGE, } \\
\text { Fluorescence } \\
\text { Imaging, } \\
\text { Western Blotting, } \\
\text { ELISA }\end{array}$ & $\begin{array}{l}\text { High level } \\
\text { production of } \\
\text { monoclonal } \\
\text { antibodies }\end{array}$ & [163] \\
\hline $\begin{array}{l}\text { Nicotiana } \\
\text { tabacum } \\
\text { (Tobacco) }\end{array}$ & Solanaceae & $\begin{array}{l}\text { N. tabacum cv. } \\
\text { Samsun and } \\
\text { Xanthi, and N. } \\
\text { benthamiana }\end{array}$ & $\begin{array}{l}\text { Human } \\
\text { interferon- } \gamma \\
(h I F N-\gamma) \\
\text { protein }\end{array}$ & Leaf & $\begin{array}{c}\text { Syringe } \\
\text { (needleless) }\end{array}$ & $\begin{array}{l}\text { EHA101, } \\
\text { GV3101, and } \\
\text { LBA4404 }\end{array}$ & pGEM-hIFN- $\gamma$ & $\begin{array}{l}\text { Best Agrobacterium } \\
\text { strain GV3101 with } \\
\text { OD600 of } 1.0 \text { and } \\
\text { acetosyringone } \\
200 \mu \mathrm{M} \text { at } 4 \text { days } \\
\text { post agroinfiltration }\end{array}$ & $\begin{array}{l}\text { Reverse Tran- } \\
\text { scription poly- } \\
\text { merase chain } \\
\text { reaction (RT-PCR), } \\
\text { qRT-PCR, SDS- } \\
\text { PAGE, Western } \\
\text { Blotting, ELISA } \\
\end{array}$ & $\begin{array}{c}\text { Bioactive hIFN- } \gamma \\
\text { protein } \\
\text { production }\end{array}$ & [164] \\
\hline $\begin{array}{l}\text { Pisum } \\
\text { sativum } \\
\text { (Pea) }\end{array}$ & Fabaceae & $\begin{array}{l}\text { Pisum sativum } \\
\text { and Medicago } \\
\text { sativa } \\
\text { plants }\end{array}$ & Salivary gene & Leaf & $\begin{array}{l}\text { Syringe and } \\
\text { vacuum }\end{array}$ & AGL-1 & pEAQ-HT-DEST1 & $\begin{array}{l}\text { Screening of a range } \\
\text { of pea cultivars }\end{array}$ & $\begin{array}{c}\text { Protein } \\
\text { extraction and } \\
\text { Western-Blotting }\end{array}$ & $\begin{array}{l}\text { Increase aphids } \\
\text { fecundity }\end{array}$ & [165] \\
\hline $\begin{array}{l}\text { Solanum } \\
\text { lycopersicum } \\
\text { (Tomato) } \\
\text { and } \\
\text { Nicotiana } \\
\text { benthamiana } \\
\text { (Tobacco) }\end{array}$ & Solanaceae & $\begin{array}{l}\text { MicroTom, a } \\
\text { dwarf tomato } \\
\text { cultivar }\end{array}$ & GFP & Leaf & $\begin{array}{c}\text { Syringe } \\
\text { (needleless) }\end{array}$ & EHA105 & $\begin{array}{c}\text { pCASGFPt } \\
\text { (control GFP), } \\
\text { pOsAPP1GFP } \\
\text { (pGFPTag16) and } \\
\text { pOsZF1GFP } \\
\text { (pZF1gfp) }\end{array}$ & $\begin{array}{c}\text { Testing of } \\
\text { agroinfiltration by } \\
\text { expressing GFP } \\
\text { fusions of the puta- } \\
\text { tive antiphagocytic } \\
\text { protein } 1 \text { (APP1) } \\
\text { (OsAPP, LOC_- } \\
\text { Os03g56930) and } \\
\text { ZOS3-18-C2H2 } \\
\text { zinc-finger protein } \\
\text { (OsZF1, LOC_- } \\
\text { Os03g55540) }\end{array}$ & GUS staining & $\begin{array}{l}\text { Subcellular } \\
\text { localization of } \\
\text { proteins }\end{array}$ & [166] \\
\hline
\end{tabular}


Table 1. Cont.

\begin{tabular}{|c|c|c|c|c|c|c|c|c|c|c|c|}
\hline Plant & Family & $\begin{array}{c}\text { Cultivar/ } \\
\text { Genotype (s) }\end{array}$ & Target Gene & Tissue & Method & $\begin{array}{l}\text { Agrobacterium } \\
\text { Strain (s) }\end{array}$ & Binary Vector (s) & $\begin{array}{l}\text { Optimization for } \\
\text { Agroinfiltration }\end{array}$ & $\begin{array}{l}\text { Detection } \\
\text { Methods }\end{array}$ & Remarks & Reference \\
\hline \multicolumn{12}{|c|}{ Floricultural crops } \\
\hline $\begin{array}{l}\text { Cannabis } \\
\text { sativa L. } \\
\text { (Hemp) }\end{array}$ & Cannabaceae & $\begin{array}{c}\text { Fedora 17, } \\
\text { Felina 32, } \\
\text { Ferimon, } \\
\text { Futura 75, } \\
\text { Santhica 27 } \\
\text { and USO31 }\end{array}$ & $\begin{array}{c}\text { Phytoene } \\
\text { Desaturase } \\
\text { (PDS) and } \\
\text { GUS }\end{array}$ & $\begin{array}{c}\text { Plant } \\
\text { tissue- } \\
\text { mature } \\
\text { leaf discs, } \\
\text { mature } \\
\text { leaf, } \\
\text { pollen } \\
\text { sacs, } \\
\text { anthers, } \\
\text { sepals, } \\
\text { pollen sac } \\
\text { clusters, } \\
\text { filaments, } \\
\text { pollen } \\
\text { grains, } \\
\text { nonglan- } \\
\text { dular } \\
\text { trichomes, } \\
\text { female } \\
\text { flowers } \\
\text { and pistil }\end{array}$ & Vacuum & $\begin{array}{l}\text { EHA105, } \\
\text { LBA4404 and } \\
\text { GV3101 }\end{array}$ & $\begin{array}{l}\text { pEarleyGate } \\
\text { 101-uidA }\end{array}$ & $\begin{array}{l}\text { Silwett L-770 } \\
(0.015 \%) \text {, ascorbic } \\
\text { acid }(5 \mathrm{~mm}) \text { and } \\
\text { sonication of } 30 \mathrm{~s} \\
\text { followed by a } \\
\text { 10-min vacuum } \\
\text { treatment }\end{array}$ & qRT-PCR & $\begin{array}{l}\text { Highest GUS } \\
\text { expression in the } \\
\text { leaf, stem, root } \\
\text { tissues, male and } \\
\text { female flowers }\end{array}$ & [167] \\
\hline $\begin{array}{l}\text { Eustoma } \\
\text { russullianus } \\
\text { (Lisianthus) }\end{array}$ & Gentianaceae & - & GUS & Pollen & Vacuum & LBA4404 & pBI121 & $\begin{array}{c}\text { Sucrose } 7-15 \% \\
\text { pH 5.5-7.0 } \\
\text { Temperature } \\
20-27^{\circ} \mathrm{C}\end{array}$ & $\begin{array}{c}\text { GUS assay, } \\
\text { Southern } \\
\text { hybridization } \\
\text { and RT-PCR }\end{array}$ & $\begin{array}{c}\text { Pollen } \\
\text { transformation }\end{array}$ & [168] \\
\hline $\begin{array}{c}\text { Gerbera } \\
\text { jemosonii } \\
\text { (Gerbera) }\end{array}$ & Asteraceae & $\begin{array}{l}\text { Express and } \\
\text { White Grizzly }\end{array}$ & $\begin{array}{l}\text { GUS, GFP, } \\
\text { iris-dfr and } \\
\text { petunia-f3' } 3^{\prime} h\end{array}$ & Flower & $\begin{array}{l}\text { Syringe and } \\
\text { vacuum }\end{array}$ & GV3101 & $\begin{array}{l}\text { pCambia/dfr and } \\
\text { pFGC5941 }\end{array}$ & $\begin{array}{l}\text { Vacuum infiltration } \\
\text { prove to be the best } \\
\text { method }\end{array}$ & $\begin{array}{l}\text { GFP and } \\
\text { GUS assay }\end{array}$ & $\begin{array}{l}\text { Change in the } \\
\text { anthocyanin } \\
\text { pigment }\end{array}$ & [169] \\
\hline $\begin{array}{l}\text { Piper } \\
\text { colubrinum } \\
\text { Link (Black } \\
\text { pepper) }\end{array}$ & Piperaceae & - & $\begin{array}{l}\text { GUS and } \\
\text { Serine threonine } \\
\text { protein kinase } \\
\text { (STPK) gene }\end{array}$ & $\begin{array}{l}\text { Detached } \\
\text { Leaf }\end{array}$ & Vacuum & EHA 105 & $\begin{array}{l}\text { pCAMBIA } 1305.2 \\
\text { and pHELLSGATE }\end{array}$ & $\begin{array}{l}\text { Higher vacuum } \\
\text { up to } 400-600 \mathrm{~mm} \\
\mathrm{Hg} \text { increased } \\
\text { infiltration } \\
\text { transformation } \\
\text { efficiency }\end{array}$ & qRT-PCR & $\begin{array}{l}\text { Silencing of } \\
\text { STPK gene }\end{array}$ & [170] \\
\hline
\end{tabular}


Table 1. Cont.

\begin{tabular}{|c|c|c|c|c|c|c|c|c|c|c|c|}
\hline Plant & Family & $\begin{array}{c}\text { Cultivar/ } \\
\text { Genotype (s) }\end{array}$ & Target Gene & Tissue & Method & $\begin{array}{l}\text { Agrobacterium } \\
\text { Strain (s) }\end{array}$ & Binary Vector (s) & $\begin{array}{l}\text { Optimization for } \\
\text { Agroinfiltration }\end{array}$ & $\begin{array}{l}\text { Detection } \\
\text { Methods }\end{array}$ & Remarks & Reference \\
\hline $\begin{array}{c}\text { Vitis } \\
\text { vinifera L. } \\
\text { (Grapevine) }\end{array}$ & Vitaceae & $\begin{array}{c}\text { Sugraone, } \\
\text { Aleatico, } \\
\text { Moscato Giallo } \\
\text { and Aglianico }\end{array}$ & $\begin{array}{c}\text { Free GFP and } \\
\text { (mRFP1), } \\
\text { GFP::HDEL, } \\
\text { GAPA1::YFP } \\
\text { and } b:: G F P\end{array}$ & Leaf & $\begin{array}{c}\text { Syringe } \\
\text { (needleless) }\end{array}$ & $\begin{array}{l}\text { LBA4404, } \\
\text { GV3101 and } \\
\text { AGL1 }\end{array}$ & $\begin{array}{c}\text { pBI121, } \\
\text { pBIN-m-gfp5-ER, } \\
\text { pAVA554, } \\
\text { pRSET-mRFP1, } \\
\text { pAVA554 and } \\
\text { pGreen } 0029\end{array}$ & $\begin{array}{l}\text { Combination of } \\
\text { sugraone cultivar } \\
\text { and the GV3101 } \\
\text { showed high gene } \\
\text { expression }\end{array}$ & GFP imaging & $\begin{array}{l}\text { Compatibility } \\
\text { between } \\
\text { Agrobacterium } \\
\text { strain and } \\
\text { genotype } \\
\text { exhibited high } \\
\text { transient gene } \\
\text { expression }\end{array}$ & [139] \\
\hline \multicolumn{12}{|c|}{ Horticultural crops } \\
\hline $\begin{array}{l}\text { Maesa } \\
\text { lanceolata } \\
\text { (False } \\
\text { assegai) }\end{array}$ & Primulaceae & - & GFP & Leaf & Syringe & $\begin{array}{l}\text { C58, EHA101, } \\
\text { EHA105, } \\
\text { LBA4404, } \\
\text { GV3301, } \\
\text { GV2260 and } \\
\text { pMP90 }\end{array}$ & pK7FWGF2 & $\begin{array}{l}\text { A. tumefaciens strain } \\
\text { LBA4404 at an } \\
\text { OD } 600=1.0 \text { in the } \\
\text { presence of } 100 \mu \mathrm{M} \\
\text { acetosyringone and } \\
\text { in the absence of } \\
\text { viral suppressor } \\
\text { construct }\end{array}$ & PCR & $\begin{array}{l}\text { Saponin } \\
\text { production }\end{array}$ & [172] \\
\hline $\begin{array}{l}\text { Malus } \\
\text { domestica } \\
\text { Borkh- } \\
\text { (Apple), } \\
\text { Pyrus communis } \\
\text { L. (Pear) }\end{array}$ & Rosaceae & $\begin{array}{l}\text { Apple 'Gala' } \\
\text { and Pear } \\
\text { 'Conference' }\end{array}$ & GUS & Leaf & Vacuum & EHA105 & pBBR1MCS-5 & $\begin{array}{l}\text { Silwet L-77 at a low } \\
\text { concentration } \\
(0.002 \% v / v)\end{array}$ & $\begin{array}{c}\text { Optimising } \\
\text { through } 10 \\
\text { different binary } \\
\text { plasmids and } A \text {. } \\
\text { tumefaciens } \\
\text { inoculations }\end{array}$ & $\begin{array}{c}\text { Transformation } \\
\text { efficiency } \\
\text { between } 50 \\
\text { and } 80 \%\end{array}$ & [173] \\
\hline \multicolumn{12}{|c|}{ Leguminous crop } \\
\hline $\begin{array}{l}\text { Mucuna } \\
\text { bracteata }\end{array}$ & Fabaceae & - & $\begin{array}{c}\text { Anti- } \\
\text { toxoplasma } \\
\text { immunoglobu- } \\
\text { lin }\end{array}$ & Leaf & Vacuum & GV3101 & pTRAkcHcLcTg130 & $\begin{array}{l}\text { High expression in } \\
\text { bottom trifoliate } \\
\text { leaf at } 2 \text { days } \\
\text { post-infiltration }\end{array}$ & $\begin{array}{l}\text { Western blotting } \\
\text { and ELISA }\end{array}$ & $\begin{array}{l}\text { Transient expres- } \\
\text { sion in M. bracteata, } \\
\text { was two-fold } \\
\text { higher than the } \\
\text { model Nicotiana } \\
\text { benthamiana plant }\end{array}$ & [174] \\
\hline
\end{tabular}


Table 1. Cont.

\begin{tabular}{|c|c|c|c|c|c|c|c|c|c|c|c|}
\hline Plant & Family & $\begin{array}{c}\text { Cultivar/ } \\
\text { Genotype (s) }\end{array}$ & Target Gene & Tissue & Method & $\begin{array}{c}\text { Agrobacterium } \\
\text { Strain (s) }\end{array}$ & Binary Vector (s) & $\begin{array}{l}\text { Optimization for } \\
\text { Agroinfiltration }\end{array}$ & $\begin{array}{l}\text { Detection } \\
\text { Methods }\end{array}$ & Remarks & Reference \\
\hline \multicolumn{12}{|c|}{ Vegetable Crop } \\
\hline $\begin{array}{l}\text { Spinacia } \\
\text { oleracea } \\
\text { (Spinach) }\end{array}$ & Chenopodiaceae & $\begin{array}{l}\text { Korean } \\
\text { cultivar } \\
\text { Sakyechul }\end{array}$ & GUS & Leaf & $\begin{array}{c}\text { Syringe } \\
\text { (needleless) } \\
\text { and vacuum }\end{array}$ & $\begin{array}{l}\text { EHA105, } \\
\text { LBA4404 and } \\
\text { GV2260 }\end{array}$ & pB7WG2D-GUS & $\begin{array}{l}\text { Agrobacterium } \\
\text { GV2260 strain } \\
\text { suspension at } \\
\text { OD600 of } 1.0\end{array}$ & qRT-PCR & $\begin{array}{l}\text { Increased } \\
\text { efficiency, } \\
\text { duration of } \\
\text { gene expression } \\
\text { and protein } \\
\text { accumulation }\end{array}$ & [97] \\
\hline \multicolumn{12}{|c|}{ Vegetable and model crops } \\
\hline $\begin{array}{l}\text { Lactuca ser- } \\
\text { riola and } \\
\text { L. sativa } \\
\text { (Lettuce), } \\
\text { Lycopersicon } \\
\text { esculentum } \\
\text { (Tomato), N. } \\
\text { benthamiana } \\
\text { (Tobacco) } \\
\text { and Ara- } \\
\text { bidopsis } \\
\text { thaliana (Ara- } \\
\text { bidopsis) }\end{array}$ & $\begin{array}{c}\text { Asteraceae, } \\
\text { Solanaceae } \\
\quad \text { and } \\
\text { Brassicaceae }\end{array}$ & $\begin{array}{l}\text { Wild lettuce } \\
\text { LS102, } \\
\text { cultivated } \\
\text { lettuce cv. } \\
\text { Valmaine and } \\
\text { cv. Mariska, } \\
\text { tomato-Rio } \\
\text { Grande 76R, } \\
\text { Arabidopsis- } \\
\text { Columbia-0 }\end{array}$ & GUS & Leaf & $\begin{array}{c}\text { Syringe } \\
\text { (needleless) }\end{array}$ & 42 wild strains & $\begin{array}{l}\text { pCB301'empty', } \\
\text { tobacco etch } \\
\text { virus-P1/HcPro, } \\
\text { turnip mosaic } \\
\text { virus-P1/HcPro } \\
\text { and P19 from } \\
\text { tomato bushy } \\
\text { stunt virus }\end{array}$ & $\begin{array}{l}\text { Best Agrobacterium } \\
\text { strain C } 58 \mathrm{C} 1\end{array}$ & GUS assay & $\begin{array}{l}\text { High gene } \\
\text { expression in } \\
\text { lettuce as } \\
\text { compared to } \\
\text { Nicotiana } \\
\text { benthamiana }\end{array}$ & [88] \\
\hline $\begin{array}{l}\text { Nicotiana to- } \\
\text { bacum (To- } \\
\text { bacco), Solanum } \\
\text { tuberosum } \\
\text { (Potato) and } \\
\text { Lactuca sativa } \\
\text { (Lettuce) }\end{array}$ & $\begin{array}{c}\text { Solanaceae } \\
\text { and } \\
\text { Asteraceae }\end{array}$ & $\begin{array}{l}\text { Nicotiana } \\
\text { tobacum cv. } \\
\text { Xanthi, } \\
\text { Solanum } \\
\text { tuberosum cv. } \\
\text { Agria }\end{array}$ & $\begin{array}{l}\text { Human growth } \\
\text { hormone }\end{array}$ & Leaf & Vacuum & pGV3850 & pBin19 & $\begin{array}{l}\text { Time span of } \\
\text { infiltration upto } \\
35 \mathrm{~min}\end{array}$ & $\begin{array}{l}\text { Western blotting } \\
\text { and ELISA }\end{array}$ & $\begin{array}{l}\text { High production } \\
\text { of recombinant } \\
\text { hGH protein in } \\
\text { tobacco and } \\
\text { potato as } \\
\text { compared } \\
\text { to lettuce }\end{array}$ & [175] \\
\hline
\end{tabular}


Cytoplasmic RNA silencing may occur during agroinfiltration transient expression [176]. Recently, Norkunas et al. [118] have identified the effects of chemical additives and heat shock pretreatment to confer improved transformation through agroinfiltration in Nicotiana tabacum. The construct comprised of the geminiviral replication system and a double terminator including heat shock protein terminator combined with an extensin terminator can also increase transient protein expression during the agroinfiltration process [177]. Hyperosmotic pretreatment with sucrose $(25 \% w / v)$ containing $1 / 2 \mathrm{MS}$ solution ( $\mathrm{pH} 5.8)$ for $3 \mathrm{~h}$ before agroinfiltration greatly improved transient expression efficiency [109]. Sheludko [29] reviewed the optimization of transient expression protocol for high-scale protein production. The leaf position of apical leaves showed high transient GFP expression [140]. The transient transformation efficiency of $99-100 \%$ in recalcitrant banana plants was achieved by using hydroponic solution followed by syringe-based infiltration [178].

\section{Advantages of Agroinfiltration Method over Other Transient Genetic Transformation Methods}

Various genetic transformation methods for transient genetic transformation in plants include PEG-mediated, biolistics, viral vectors, and agroinfiltration. Agroinfiltration exhibits numerous advantages over the above-mentioned transient methods which are briefly summarized here. Agroinfiltration process does not involve isolation of protoplast which is a pre-requisite for the PEG-mediated genetic transformation. Further, agroinfiltration is a simple and cost-effective method that simply involves the infiltration of transgenes into the intercellular layers of plant cells $[7,118]$. Moreover, agroinfiltration is less time-consuming compared to the protoplasts-based genetic transformation [179].

The high-velocity biolistics method also exhibits a transient expression of an introduced gene(s) in the plant cells. This method was first demonstrated in the laboratory of J.C. Sanford at Cornell University in the late 1980s [8]. But this rapid and versatile method suffers from a major limitation of the requirement of special equipment PDS-1000/He [32]. Moreover, the transformation efficiency of biolistics is relatively low as compared to agroinfiltration [180]. The efficiency of promoters can be tested efficiently in agroinfiltration as compared to the biolistics genetic transformation method [181].

The transient expression was also achieved using viral vectors but this method suffered from biosafety and construct-size limitation issues for the insertion of transgenes [152,182]. Contrastingly, agroinfiltration involved the infiltration of the whole leaf with one or multiple target DNA constructs or introducing multiple constructs into the different regions of the same leaf [135]. Thus, agroinfiltration is a better suited transient genetic transformation method compared to biolistics, viral vectors, and PEG-mediated methods in plants.

\section{CRISPR-Cas9 Based Genome Editing via Agroinfiltration}

The CRISPR/Cas9 system can be effectively coupled with the agroinfiltration transient expression system thereby employing the delivery or use of Cas9 and sgRNA for targeted site modifications in plants (Figure 2). The conjugation of CRISPR/Cas9 (primary choice for plant genome editing) and Agrobacterium-mediated transformation (most preferred method for gene delivery) has the power to deliver the CRISPR/Cas9 DNA constructs efficiently to plants without integration into the plant cells [183]. Generally, agroinfiltration forms a part of the initial screening used as a preliminary experiment to identify whether a particular plant tissue type is amenable to transformation or not which is indirectly validated through the sgRNA expression (genome editing) or genetic transformation ( $g f p$ gene or other gene studies). The studies linked to the use of agroinfiltration-based CRISPR-Cas9 genome editing in plants have been given in Table 2. The non-transmissible agroinfiltration approach serves as the first line of experiments to test the extent of transient genome editing before initiating the elaborate genome editing experiments. Contrastingly, a recent comprehensive review is available that emphasizes the use of Agrobacterium-based floral dip stable transformation for genome editing [4]. The focus on the Agrobacteriumbased transient gene transformation agroinfiltration method in genome editing bears better advantages over the Agrobacterium-based stable genetic transformation methods. 
The transient agroinfiltration approach is widely employed for the prediction of gRNA efficiency in genome editing constructs in vivo (Table 2). The combinatorial approach of CRISPR-Cas editing and agroinfiltration showed the result in the transformed tissue within 3 days after infiltration that serve as a reliable assay for testing sgRNAs under native conditions [184]. 
Table 2. Agroinfiltration based genome editing strategies for plants.

\begin{tabular}{|c|c|c|c|c|c|c|c|c|c|c|c|c|}
\hline Plant & Family & $\begin{array}{l}\text { Cultivar/ } \\
\text { Genotype }\end{array}$ & Target & Tissue & Stage & Method & $\begin{array}{l}\text { Agrobacterium } \\
\text { Strain }\end{array}$ & Promoter & $\begin{array}{l}\text { Cas9-Codon } \\
\text { Optimised }\end{array}$ & Detection Assay & $\begin{array}{c}\text { Mutation } \\
\text { Rate }\end{array}$ & Reference \\
\hline \multicolumn{13}{|c|}{ Model plants } \\
\hline $\begin{array}{l}\text { Arabidopsis } \\
\text { thaliana } \\
\text { (Arabidopsis) }\end{array}$ & Brassicaceae & Columbia- 0 & PDS & Seedlings & 2-week-old & $\begin{array}{c}\text { Syringe } \\
\text { (needleless) }\end{array}$ & GV3101 & $\begin{array}{l}\text { CaMV35SPDK } \\
\text { and AtU6 }\end{array}$ & Yes & $\begin{array}{l}\text { PCR and Sanger } \\
\text { sequencing }\end{array}$ & $2.7 \%$ & [185] \\
\hline $\begin{array}{l}\text { Arabidopsis } \\
\text { thaliana } \\
\text { (Arabidopsis) }\end{array}$ & Brassicaceae & $\begin{array}{l}\text { Transgenic } \\
\text { plants }\end{array}$ & GFP & Leaf & 4-week-old & $\begin{array}{c}\text { Syringe } \\
\text { (needleless) }\end{array}$ & $\begin{array}{l}\text { C58 and } \\
\text { EHA105 }\end{array}$ & $\begin{array}{l}\text { CaMV35S } \\
\text { and AtU6 }\end{array}$ & Yes & $\begin{array}{c}\text { Fluorescence } \\
\text { confocal } \\
\text { microscopy and } \\
\text { Sangersequencing }\end{array}$ & - & [186] \\
\hline \multirow{7}{*}{$\begin{array}{l}\text { Nicotiana } \\
\text { benthamiana } \\
\text { (Tobacco) }\end{array}$} & \multirow{7}{*}{ Solanaceae } & - & PDS & Leaf & 5-week-old & $\begin{array}{c}\text { Syringe } \\
\text { (needleless) }\end{array}$ & GV3101 & $\begin{array}{l}\text { CaMV35SPDK } \\
\text { and AtU6 }\end{array}$ & Yes & $\begin{array}{l}\text { PCR and Sanger } \\
\text { sequencing }\end{array}$ & $4.8 \%$ & [185] \\
\hline & & - & PDS & Leaf & 3-4 weeks & $\begin{array}{c}\text { Syringe } \\
\text { (needleless) }\end{array}$ & AGL1 & $\begin{array}{l}\text { CaMV35S } \\
\text { and AtU6 }\end{array}$ & Yes & $\begin{array}{l}\text { PCR and restriction } \\
\text { enzyme assay }\end{array}$ & $2.1 \%$ & [187] \\
\hline & & - & PDS & Leaf & 3-4 weeks & Syringe & GV3101 & CaMVE35S & - & $\begin{array}{c}\text { RT-PCR and Sanger } \\
\text { sequencing }\end{array}$ & $12.7-13.8 \%$ & [188] \\
\hline & & - & PDS & Leaf & 3-4 weeks & Syringe & GV3101 & BS3 and uid & Yes & $\begin{array}{c}\text { qRT-PCR and } \\
\text { Sanger sequencing }\end{array}$ & - & [189] \\
\hline & & - & PDS & Leaf & 3-week-old & $\begin{array}{c}\text { Syringe } \\
\text { (needleless) }\end{array}$ & AGL1 & $\mathrm{J} 23119$ & - & $\begin{array}{l}\text { PCR, Sanger and } \\
\text { Illumina } \\
\text { sequencing }\end{array}$ & $3-18 \%$ & [191] \\
\hline & & $\begin{array}{l}\text { Transgenic } \\
\text { plants }\end{array}$ & $\begin{array}{c}\text { Six sites Bean yellow } \\
\text { dwarf virus genome-- } \\
\text { Rep binding site (RBS), } \\
\text { hairpin, nonanucleotide } \\
\text { sequence and three } \\
\text { Rep motifs }\end{array}$ & Leaf tips & 5-week-old & Syringe & GV3101 & $\begin{array}{c}\text { Double } 35 S \\
\text { promoter and } \\
\text { AtU6 or } \\
\text { At7SL RNA } \\
\text { polymerase } \\
\text { III promoter }\end{array}$ & - & $\begin{array}{l}\text { qRT-PCR and } \\
\text { Illumina } \\
\text { sequencing }\end{array}$ & $\begin{array}{c}0.03- \\
70.01 \%\end{array}$ & [192] \\
\hline & & - & Xylosyltransferase gene & Leaf & 5-6 weeks & $\begin{array}{c}\text { Syringe } \\
\text { (needleless) }\end{array}$ & GV3101 & $\begin{array}{l}\text { Nopaline } \\
\text { synthase }\end{array}$ & Yes & $\begin{array}{l}\text { PCR, restriction } \\
\text { digestion analysis } \\
\text { and Sanger } \\
\text { sequencing }\end{array}$ & $\begin{array}{c}12.1 \%- \\
X T 1 \text { and } \\
9.9 \%-X T 2\end{array}$ & [193] \\
\hline
\end{tabular}


Table 2. Cont.

\begin{tabular}{|c|c|c|c|c|c|c|c|c|c|c|c|c|}
\hline Plant & Family & $\begin{array}{l}\text { Cultivar/ } \\
\text { Genotype }\end{array}$ & Target & Tissue & Stage & Method & $\begin{array}{l}\text { Agrobacterium } \\
\text { Strain }\end{array}$ & Promoter & $\begin{array}{l}\text { Cas9-Codon } \\
\text { Optimised }\end{array}$ & Detection Assay & $\begin{array}{c}\text { Mutation } \\
\text { Rate }\end{array}$ & Reference \\
\hline \multirow{4}{*}{$\begin{array}{l}\text { Nicotiana } \\
\text { tabacum } \\
\text { (Tobacco) }\end{array}$} & \multirow{4}{*}{ Solanaceae } & $\begin{array}{l}\text { Cas9- } \\
\text { overexpressing } \\
\text { transgenic } \\
\text { lines }\end{array}$ & $\begin{array}{l}\text { PDS and proliferating } \\
\text { cell nuclear antigen } \\
\text { gene (PCNA) genes }\end{array}$ & Leaf & - & Syringe & GV3101 & CaMV 35S & Yes & $\begin{array}{l}\text { T7 endonuclease } \\
1 \text { based assay, } \\
\text { restriction } \\
\text { digestion analysis } \\
\text { and Sanger } \\
\text { sequencing }\end{array}$ & - & [194] \\
\hline & & - & PDS & Leaf & - & $\begin{array}{c}\text { Syringe } \\
\text { (needleless) }\end{array}$ & $\begin{array}{l}\text { EHA105 and } \\
\text { GV3101 }\end{array}$ & AtU6 & Yes & $\begin{array}{l}\text { PCR and Sanger } \\
\text { sequencing }\end{array}$ & - & [195] \\
\hline & & - & PDS & Leaf & 3-4 weeks & Syringe & GV3101 & 35SPDK & Yes & $\begin{array}{l}\text { Flourescent } \\
\text { microscopy and } \\
\text { PCR analysis }\end{array}$ & - & [196] \\
\hline & & Wild-type & GFP & Leaf & 4-week-old & $\begin{array}{c}\text { Syringe } \\
\text { (needleless) }\end{array}$ & $\begin{array}{l}\text { C58 and } \\
\text { EHA105 }\end{array}$ & $\begin{array}{l}\text { CaMV35S } \\
\text { and AtU6 }\end{array}$ & Yes & $\begin{array}{c}\text { Fluorescence } \\
\text { confocal } \\
\text { microscopy and } \\
\text { Sanger sequencing }\end{array}$ & - & [186] \\
\hline $\begin{array}{l}\text { Solanum } \\
\text { lycopersicum } \\
\text { (Tomato) }\end{array}$ & Solanaceae & $\begin{array}{l}\text { Transgenic } \\
\text { plants }\end{array}$ & $\begin{array}{c}\text { Immunity associated } \\
\text { genes }\end{array}$ & Leaf & 4-week-old & $\begin{array}{c}\text { Syringe } \\
\text { (needleless) }\end{array}$ & 1D1249 & U6 promoter & - & $\begin{array}{l}\text { PCR and Sanger } \\
\text { sequencing }\end{array}$ & $61.5 \%$ & [96] \\
\hline $\begin{array}{l}\text { Sorghum } \\
\text { bicolor } \\
\text { (Sorghum) }\end{array}$ & Poaceae & Tx430 plants & GFP & Leaf & 3-4 weeks & $\begin{array}{c}\text { Syringe } \\
\text { (needleless) }\end{array}$ & GV3101 & $\begin{array}{l}\text { CaMV 35S } \\
\text { and maize } \\
\text { Ubiquitin } 1\end{array}$ & Yes & $\begin{array}{l}\text { Fluorescence } \\
\text { microscopy }\end{array}$ & - & [184] \\
\hline \multicolumn{13}{|c|}{ Horticultural crops } \\
\hline $\begin{array}{l}\text { Citrus } \\
\text { sinensis } \\
\text { (Sweet } \\
\text { Orange) }\end{array}$ & Rutaceae & $\begin{array}{l}\text { Valencia } \\
\text { cultivar }\end{array}$ & PDS & Leaf & $\begin{array}{l}\text { Three-year- } \\
\text { old }\end{array}$ & Syringe & - & CaMV $35 S$ & - & $\begin{array}{l}\text { PCR and Sanger } \\
\text { sequencing }\end{array}$ & $3.2-3.9 \%$ & [197] \\
\hline $\begin{array}{c}\text { Citrus } \\
\text { paradisi } \\
\text { (Grapefruit) }\end{array}$ & Rutaceae & $\begin{array}{l}\text { Wild type } \\
\text { Duncan and } \\
\text { transgenic } \\
\text { plants }\end{array}$ & $\begin{array}{c}\text { Canker susceptibility } \\
\text { gene } \\
\text { (CsLOB1) }\end{array}$ & Leaf & - & $\begin{array}{c}\text { Syringe } \\
\text { (needleless) }\end{array}$ & EHA105 & $\begin{array}{c}\text { Cassava vein } \\
\text { mosaic virus } \\
\text { promoter } \\
\text { and CaMV } \\
35 \mathrm{~S} \text { promoter }\end{array}$ & - & $\begin{array}{l}\text { Illumina } \\
\text { sequencing }\end{array}$ & $\begin{array}{c}3.58- \\
88.78 \%\end{array}$ & [198] \\
\hline
\end{tabular}


Table 2. Cont.

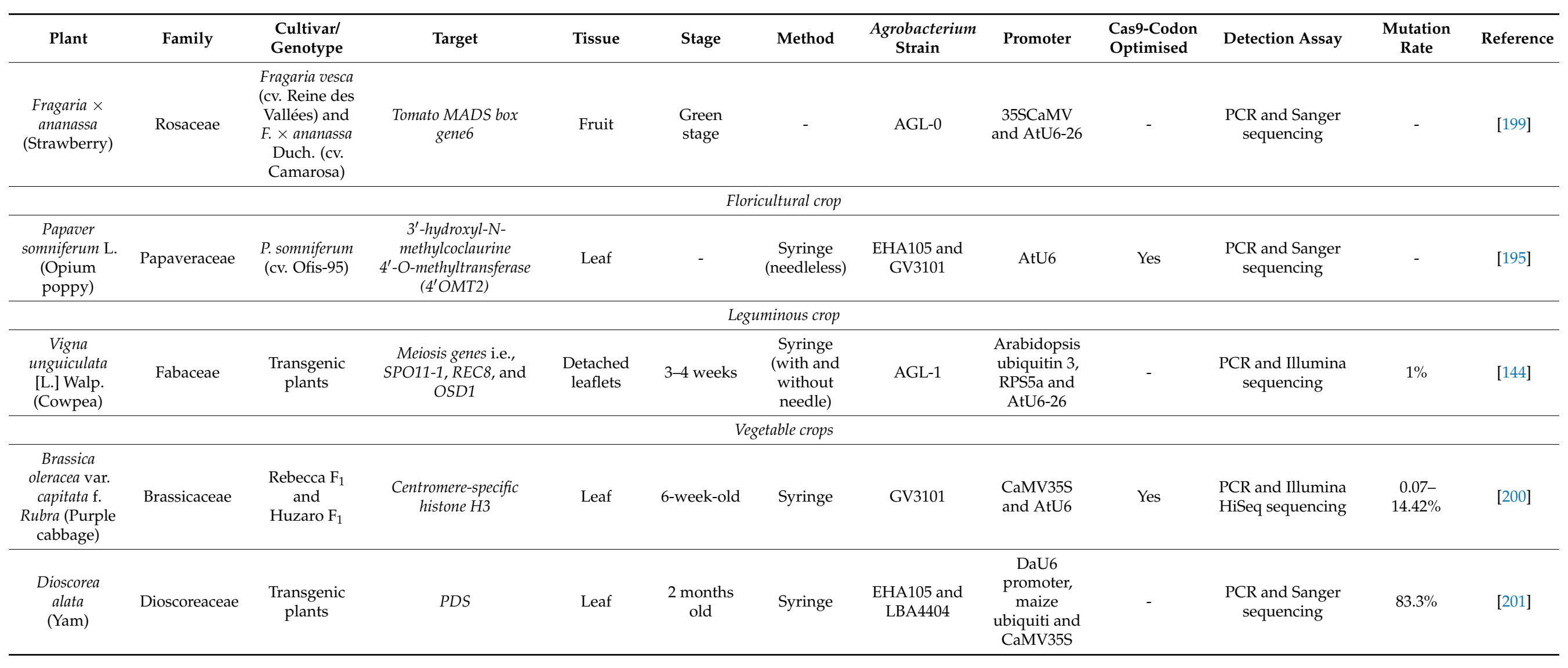


Among prevailing genome editing tools viz. CRISPR-Cas widely acceptable tool other than ZFNs and TALENs for crop improvement $[131,202,203]$. Most of the researchers targeted the PDS gene required for carotenoid biosynthesis. Li et al. [185] have utilized agroinfiltration for targeted genome modifications in the AtPDS3 and NbPDS genes of Arabidopsis thaliana and Nicotiana benthamiana. The PDS disruption enhanced the chlorophyll oxidation that led to the development of a visible photobleached phenotype $[104,185]$. The agroinfiltration was used for CRISPR/Cas9-mediated genome editing targeting PDS gene in various plant species [179,185,187-191,194-197,201]. Syombua et al. [201] have employed the Agrobacterium-based transient transformation method; agroinfiltration and genome editing for Yam (Dioscoreaalata) plant genetic improvement. The infiltration of pCas9-gRNA-PDS in leaves tends to show bleached patches that can be analyzed through microscopic examination of an infiltrated leaf section to confirm the transient knockout of the PDS gene, and the effectiveness of both agroinfiltration and genome editing approaches.

Along with PDS, researchers have also utilized another visible marker GFP to analyse the success of the agroinfiltration-based genome editing [186]. The use of non-functional GFP containing the target site cleaved by a Cas9/sgRNA complex resulted in the creation of functional GFP genes to report the success of agroinfiltration-based genome editing [186] The conversion of frame-shifted GFP to visible GFP due to CRISPR-Cas9 genome editing marks the achievement in agroinfiltration-based genome editing that can be analyzed through fluorescence microscopy of the infiltrated section [201]. Later on, the transient expression can be followed by stable genetic transformation that tend to show phenotype such as dwarf phenotype, albino shoot with a bushy phenotype, and variegated albino plantlets [201]. Besides, fluorescent markers, vectors namely pGD vectors carrying GFP and DsRed elements also ease the interpretation of co-localization and protein-protein interactions in dicots in the agroinfiltration in plants [204]. Moreover, pBYR2HS vector in agroinfiltration applies to leaves and fruits [82]. Sharma et al. [184] have developed a simplified transient transformation assay using agroinfiltration in sorghum and confirmed the gene editing in sorghum leaves using GFP as a marker. The agroinfiltration-based genome editing was used to monocot sorghum which is an unlikely host for Agrobacterium due to the occurrence of epidermal cuticular wax, high silica content, and low volume of intercellular space. However, it was observed to be a successful technique for achieving genome editing in the sorghum. The sgRNA efficiency in orange and purple cabbage has been tested using agroinfiltration $[197,200]$. Likewise, agroinfiltration transient approach has been tested followed by implementation through stable transformation for gene characterization studies in strawberry [199] (Knockout of Tomato MADS box gene6 generated mutant lines that deciphered its role in anther development), yam [201] (Knockout of PDS gene resulted in the development of albino plants) and cowpea [144] (Knockout of meiosis genes viz. SPO11-1, REC8, and OSD1 showed defects in male and female meiocytes displaying its role for the induction of mitosis from meiosis). Most of the researchers reported the leaf (Table 1) as a host for agroinfiltration-based genome editing while Baltes et al. [192] reported the agroinfiltration-based genome editing using leaf tips with $0.03-70.01 \%$ mutation rate conferring geminiviruses resistance.

Further, the repercussions of the genome edits under in vivo conditions are always subtle and not easily detectable. It has been evident that the predicted sgRNAs often have different editing efficiencies in homozygous and heterozygous conditions in each cell. Also, the variation in the knock-outs or sequences in any of the genes after genome editing events will be more useful to study the impact of genome editing or its efficiency rather than obtaining variations in the phenotypic characters. Moreover, the variation in the sequence can be easily identified through Sanger's sequencing technique under in vitro conditions. Moreover, in silico prediction tools have been utilized to analyze the editing efficiency based on the choice and sequence feature of the sgRNA [184]. 


\section{Modifications of Agroinfiltration-Based Genome Editing}

Several reports showcasing the use of modified methods for agroinfiltration-mediated genome editing in plants have appeared over the recent decade. Jia and Wang $[197,205]$ have published the first report on targeted genome modification of citrus through Xanthomonas citri subsp. citri $(\mathrm{Xcc})$-facilitated agroinfiltration to enhance the transient protein expression in a recalcitrant citrus species- Valencia sweet orange. They have recorded the involvement of PthA4Type III effector molecule and transcriptional activator-like effector leading to cell division (hyperplasia) and enlargement (hypertrophy) to be responsible for improved efficacy and success of Xcc-facilitated agroinfiltration. Jia and Wang [197,205] employed Xcc-facilitated agroinfiltration to deliver Cas9, along with a synthetic sgRNA targeting the phytoene desaturase (CsPDS) gene, into sweet orange and confirmed the mutation at the targeted location through DNA sequencing. The CRISPR-Cas9 technology employed agroinfiltration to confer resistance to tobacco rattle virus, bean yellow dwarf virus, and citrus canker accompanying targeting of numerous endogenous plant genes (Table 1) [144,190,192-195,198-200,206].

Several researchers have employed leaf for both syringe and vacuum infiltration. However, Juranic et al. [144] have illustrated the use of detached leaf rather than the intact leaf. They have interpreted that agro-infiltration of the intact leaves results in a variety of undesirable symptoms including necrosis, photo-bleaching, browning, and senescence or cell death. Hence, they have performed a detached leaf assay of leaflets with fluorescent expression constructs with the objective of meiosis-knock out for asexual seed induction in cowpea to identify gene-specific mutations.

Along with agroinfiltration, researchers have utilized the co-cultivation method as a transient transformation method [207,208]. Li et al. [207] have used this method and successfully employed the CRISPR/Cas9 technology to knock out the self-incompatibilityrelated gene SRK in Chinese cabbage with $10.83 \%$ transformation efficiency.

\section{Other Applications in Plants}

Agroinfiltration has enormous applications in plants (Table 3). It has been utilized for transient expression of transcription factor [209], antibody, and recombinant protein production [210,211]. Agroinfiltration is also applicable to effectoromics field involving rapid resistance and a virulence gene discovery [212]. Agroinfiltration has played a major role in a variety of studies including the gene silencing [122,213-217], elicitor identification [218,219], resistance mechanism [220-223], promoter characterization [224,225], expression studies [226], identification of plant receptor(s) [227], antigen-antibody interactions [228-231], vaccine production, protein ubiquitination [232], protein degradation [233], pigment [209] and phyto-sensing studies [234]. It has the potential to give a scrutinizing view of the plant system efficiently in the present times. 
Table 3. Application of agroinfiltration in plants other than genome editing after the discovery of transient expression by Kapila et al. [7].

\begin{tabular}{|c|c|c|c|c|c|c|c|c|}
\hline Plant & Target & Family & Material & Promoter & $\begin{array}{l}\text { Agrobacterium } \\
\text { Strain }\end{array}$ & Method & Outcome & Reference \\
\hline & & & & Model plants & & & & \\
\hline $\begin{array}{l}\text { Medicago truncatula } \\
\text { (Barrel clover) }\end{array}$ & $\begin{array}{l}\text { LEGUME ANTHOCYANIN } \\
\text { PRODUCTION 1 (LAP1) } \\
\text { transcription factor }\end{array}$ & Fabaceae & $\begin{array}{l}\text { Medicago truncatula } \\
\text { cv. R108 }\end{array}$ & CaMV35S & GV3101 & Syringe & $\begin{array}{c}\text { Accumulation of } \\
\text { anthocyanin pigment }\end{array}$ & [209] \\
\hline \multirow{8}{*}{$\begin{array}{l}\text { Nicotiana } \\
\text { benthamiana } \\
\text { (Tobacco) }\end{array}$} & C5-1 murine antibody & Solanaceae & $\begin{array}{l}\text { Seeds obtained from } \\
\text { National tobacco } \\
\text { germplasm }\end{array}$ & CaMV 35S & AGL1 & Syringe & $\begin{array}{l}\text { Recombinant protein } \\
\text { production at lab scale }\end{array}$ & [211] \\
\hline & $\begin{array}{c}\text { epiGFP } \\
\text { (without GFP integration) }\end{array}$ & Solanaceae & $\begin{array}{l}\text { Stably integrated } \\
\text { GFP transgene } \\
\text { (intGFP) transgenic } \\
\text { plants }\end{array}$ & CaMV35S & - & Syringe & $\begin{array}{c}\text { Systemic silencing through } \\
\text { interaction between epiGFP } \\
\text { and intGFP }\end{array}$ & [215] \\
\hline & $\begin{array}{l}\text { Ubiquitin ligase-associated } \\
\text { protein SGT1 }\end{array}$ & Solanaceae & Transgenic plants & CaMV35S & - & Syringe & $\begin{array}{l}\text { Proof of SGT1 that is required } \\
\text { for host and nonhost disease } \\
\text { resistance in plants }\end{array}$ & [222] \\
\hline & $\begin{array}{l}\text { mGFP5-er, Bt Cry } 1 A c \text {, and } \\
\text { BoPI transgene genes }\end{array}$ & Solanaceae & - & CaMV $35 S$ & GV3850 & Syringe & $\begin{array}{l}\text { Ease the detection of candidate } \\
\text { insect resistance transgenes }\end{array}$ & [223] \\
\hline & $\begin{array}{l}\text { Chimaeric human } \\
\beta 1,4 \text {-galactosyltransferase }\end{array}$ & Solanaceae & Wild-type & $\begin{array}{l}\text { CaMV 35S, Rubisco, } \\
\text { plastocyanin }\end{array}$ & $\begin{array}{l}\text { R612, R610, R621, } \\
\text { R622 and 35SHcPro }\end{array}$ & Vacuum & $\begin{array}{l}\text { High-yield antibodies } \\
\text { production with human-like } \\
\text { N-glycans }\end{array}$ & [230] \\
\hline & Haemagglutinin gene & Solanaceae & - & $\begin{array}{c}\text { Plastocyanin, chimeric } \\
\text { double } 35 \mathrm{~S}\end{array}$ & AGL1 & Vacuum & $\begin{array}{l}\text { Production of an } \\
\text { influenza vaccine }\end{array}$ & [235] \\
\hline & $\begin{array}{c}\text { E3 ligase Constitutive } \\
\text { photomorphogenic1 (COP1) and } \\
\text { its substrate HY5 }\end{array}$ & Solanaceae & Wild-type & - & EHA105 and ABI & Syringe & $\begin{array}{l}\text { Detection of protein } \\
\text { ubiquitination }\end{array}$ & [232] \\
\hline & $\begin{array}{l}\text { Foot-and-mouth disease (FMD) } \\
\text { virus P1-polyprotein (P1) and } \\
\text { VP1 (viral capsid protein 1) and E. } \\
\text { coli glutathione reductase (GOR) }\end{array}$ & Solanaceae & - & CaMV35S & LBA4404 & Syringe & $\begin{array}{l}\text { Recombinant VP1 } \\
\text { protein degradation }\end{array}$ & [233] \\
\hline $\begin{array}{l}\text { Nicotiana species } \\
\text { (Tobacco) }\end{array}$ & Cauliflower mosaic virus Gene VI & Solanaceae & $\begin{array}{l}\text { N. edwardsonii and } N . \\
\text { clevelandii }\end{array}$ & CaMV35S & C58 & $\begin{array}{c}\text { Syringe } \\
\text { (needleless) }\end{array}$ & $\begin{array}{l}\text { Identification of gene VI } \\
\text { protein elicitor }\end{array}$ & [219] \\
\hline $\begin{array}{l}\text { Nicotiana sylvestris } \\
\text { (Tobacco) }\end{array}$ & $\begin{array}{l}\text { Class I chitinase A gene } \\
\text { CHN48 transgene }\end{array}$ & Solanaceae & $\begin{array}{l}\text { Wild type and } \\
\text { transgenic plants }\end{array}$ & CaMV35S & - & Syringe & Transgene silencing & [213] \\
\hline
\end{tabular}


Table 3. Cont.

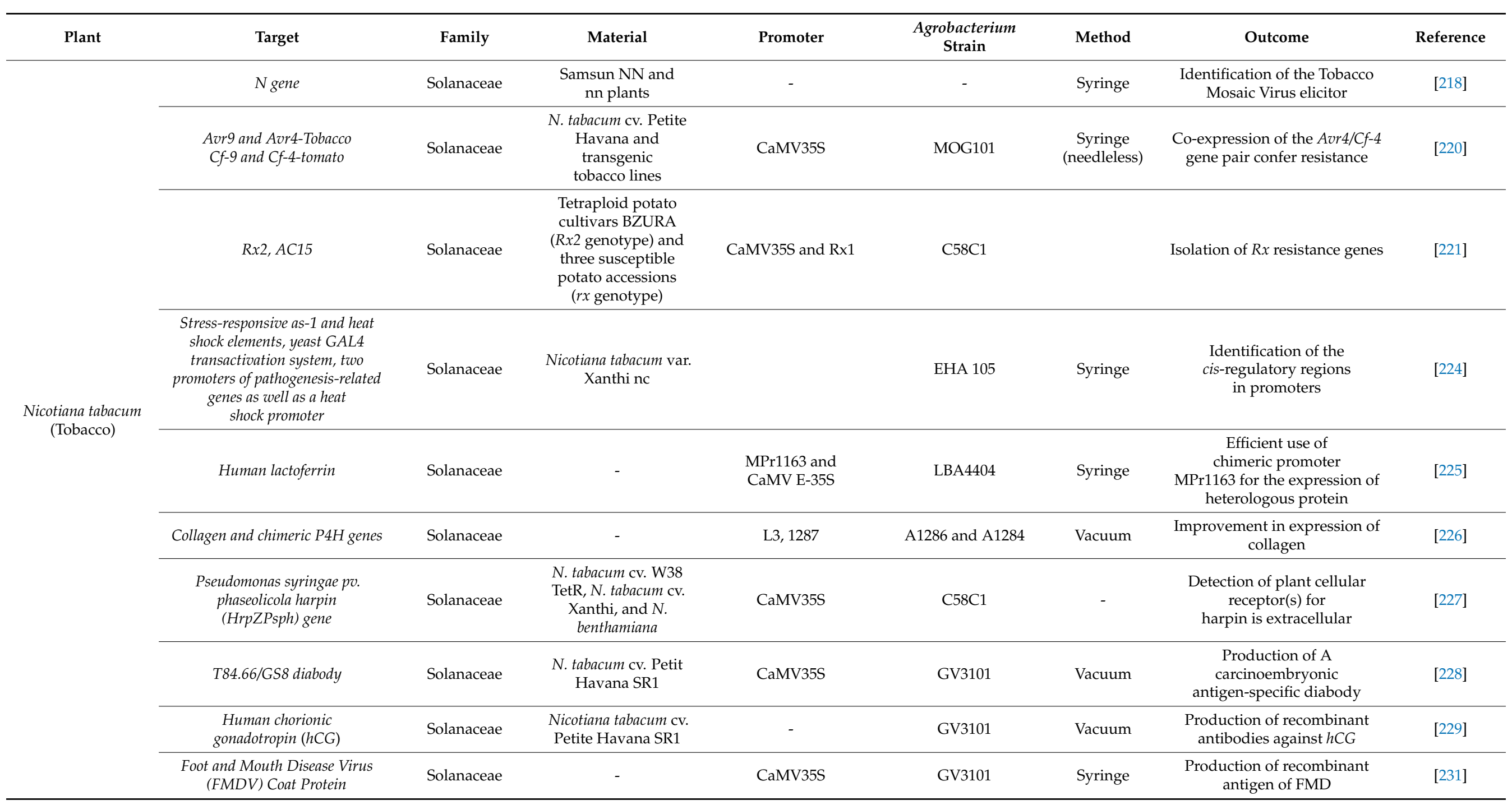


Table 3. Cont.

\begin{tabular}{|c|c|c|c|c|c|c|c|c|}
\hline Plant & Target & Family & Material & Promoter & $\begin{array}{l}\text { Agrobacterium } \\
\text { Strain }\end{array}$ & Method & Outcome & Reference \\
\hline $\begin{array}{l}\text { Glycine max } \\
\text { (Soybean) }\end{array}$ & $\begin{array}{c}\text { Coatomer subunit alpha (COPA) } \\
\text { and aquaporin } 9 \text { (AQ9) genes }\end{array}$ & Fabaceae & - & CaMV35S & EHA 105 & $\begin{array}{l}\text { Mechanical } \\
\text { abrasion } \\
\text { using car- } \\
\text { borundum }\end{array}$ & $\begin{array}{l}\text { RNA interference against } \\
\text { Tetranychus urticae }\end{array}$ & [217] \\
\hline \multicolumn{9}{|c|}{ Floricultural crops } \\
\hline $\begin{array}{l}\text { Vitis vinifera } \mathrm{L} . \\
\text { (Grapevine) }\end{array}$ & Grapevine gene VvPGIP1 & Vitaceae & Cabernet franc & CaMV35S & GV3101 & Vacuum & Transient gene silencing & [216] \\
\hline \multicolumn{9}{|c|}{ Horticultural crop } \\
\hline $\begin{array}{l}\text { Fragaria } \times \text { ananassa } \\
\quad \text { (Strawberry) }\end{array}$ & Chalcone synthase gene & Rosaceae & $\begin{array}{l}\text { F. } \times \text { ananassa } \mathrm{cv} \text {. } \\
\text { Elsanta }\end{array}$ & CaMV35 S & AGL0 & Syringe & Gene silencing & [122] \\
\hline \multicolumn{9}{|c|}{ Vegetable crops } \\
\hline $\begin{array}{l}\text { Raphanus sativus } \mathrm{L} . \\
\text { (Radish) }\end{array}$ & $\begin{array}{l}\text { Staphylococcal enterotoxin } B \\
\text { (SEB) genes }\end{array}$ & Brassicaceae & & CaMV35S & LBA4404 & Syringe & $\begin{array}{c}\text { Production of } \\
\text { Leaf-Encapsulated Vaccines }\end{array}$ & [237] \\
\hline $\begin{array}{l}\text { Solanum melongena } \\
\text { L. (Eggplant) }\end{array}$ & $\begin{array}{c}\text { Hydroxycinnamoyl CoA-quinate } \\
\text { transferase gene }\end{array}$ & Solanaceae & & $\begin{array}{l}\text { p19 protein of Tomato } \\
\text { bushy stunt virus } \\
\text { (native promoter) }\end{array}$ & GV3101 & $\begin{array}{l}\text { Syringe } \\
\text { (needle) }\end{array}$ & $\begin{array}{l}\text { Improvement in } \\
\text { chlorogenic content }\end{array}$ & [238] \\
\hline
\end{tabular}




\section{Limitations}

Although a useful technology, there are few pitfalls of Agroinfiltration which needs to be overcome through optimization of the genetic transformation factors while conducting the study as mentioned in Table 1 [239]. The major limitation of the transient expression is that it cannot be used for large-scale commercial production in seed banks due to its transient expression [240]. The complex configuration and organization of various types of plant cells foist varying low efficiency to the agroinfiltration process [33]. Also, high variability in the transformation efficiency depends on the type of Agrobacterium strains, target plant species, and specific tissues. Among the most popular methods of Agrobacterium-based genetic transformation, the syringe infiltration technique suffers from poor scalability that hinders experimental success [32]. Further, the plant defence responses are also a critical factor in genetic transformation studies [52]. Molecularly, the post-transcriptional gene silencing limits transient expression. Therefore, several viral suppressors like p19 protein of tomato bushy stunt virus have been introduced to enhance the transient expression [152].

\section{Bio-Safety and Commercialization Aspects}

The critical concern in plant biotechnology is the acceptance of genetically modified or genome-edited plants by consumers. Hence, biosafety and regulatory concerns need to be addressed before plant-based research studies. The generation of very high expression levels in a contained facility in an agroinfiltration-based transient approach minimizes the chances of biosafety-related risk [123]. Moreover, this technique has simple operation steps [241]. Although USA has already approved gene editing through Agrobacteriummediated transformations yet the advent of targeting the somatic cells i.e leaves does not allow the foreign gene to be transferred in the next generation, hence, no chance of transgene to be transferred towards the next generation. The biosafety limitations of the genetically modified organisms (GMOs) generated through genetic engineering technology [242] can be efficiently dealt via agroinfiltration transient approach due to its ability to retain transgene temporarily in the plant cells. The transgene(s) thus cannot be inherited to the next generation [243] as these do not get transferred to the reproductive tissues omitting its passage to germline. Chen et al. [32] have reported that agroinfiltration-based platform is an effective, safe, low-cost, and scalable approach for the rapid production of recombinant proteins. Besides these considerable factors, agroinfiltration employing the use of vectors from recombinant plasmids will be performed at BSL-1 level facilities can be considered as transgenics. Keeping in view the biosafety aspects, agroinfiltration can pave towards the production of marker (transgene)-free transgenic plants which will overcome the biosafety concerns and can be efficiently opted for commercialization in future. The commercial production of recombinant protein(s) suffers from biosafety and risk assessment [244]. However, the agroinfiltration technique can potentially resolve these biosafety issues for improving the commercial sustainability for cost and availability of the recombinant protein(s) in the coming eras. Further, the consumer acceptance for these products can be better ascertained as agroinfiltration is a transgene-free approach. Also, it is identified as an efficient approach to develop the marker-free plants utilizing leaf disc agroinfiltration with a marker-free plasmid vector containing the target gene in tobacco plants hence limited biosafety concerns (https:/ / www.isaaa.org/). It is now being widely used to produce commercially important recombinant proteins [245]. The production of low-yielding plant-produced recombinant proteins could be a hindrance to the commercial success of agroinfiltration [246] but the efficient use of optimized agroinfiltration-based factors can circumvent the limitation to increase the transformation efficiency in crop species.

\section{Conclusions}

Agroinfiltration coupled with genome editing holds promise for targeted site modification in the genomic sequence without the integration of the construct into the plant genome. The direct injection of Cas9-sgRNA complex in agroinfiltration process, encased 
in plasmid could edit the genes in the plant. Although CRISPR/Cas9 technology is the "Technology of choice" for editing genes as compared to TALENs and ZFNs, the combination of CRISPR/Cas9 with agroinfiltration, an in planta and transient approach makes it is a breakthrough technology by enhancing the feasibility, efficacy, and ultimately, the consumer acceptability of this technology. Further, the technique avoids the limitation of low transformation efficiency generated during stable genetic transformation methods. Moreover, agroinfiltration-based genome editing can help broaden the scope of targeted genome modification through simple, high throughput and genotype-independent genome editing approach. Thus, the convergence of genome editing (targeted site modification) and agroinfiltration (simplest approach) can improve the ease, versatility, and efficacy of plant genome transformations to achieve commercially viable and consumer-preferred plant products.

Author Contributions: Writing-Original draft preparation, M.K.; conceptualization of the idea, writing, review and editing, P.M.; review \& editing, A.K., F.K.A., E.N., K.K., K.A.A.-E. All authors have read and agreed to the published version of the manuscript.

Funding: The work is supported by the Department of Science and Technology under the WOS-A scheme with File No. SR/WOS-A/LS-610/2016. Also supported by the projects of University of Hradec Kralove (VT2019-2021) and MH CZ—DRO (UHHK, 00179906).

Acknowledgments: The authors thank Director, School of Agricultural Biotechnology, for providing the infrastructural facilities to carry out the research work.

Conflicts of Interest: The authors declare no conflict of interest.

\section{References}

1. Adli, M. The CRISPR tool kit for genome editing and beyond. Nat. Commun. 2018, 9, 1911. [CrossRef]

2. Gaj, T.; Gersbach, C.A.; Barbas, C.F. ZFN, TALEN, and CRISPR/Cas-based methods for genome engineering. Trends Biotechnol. 2013, 31, 397-405. [CrossRef] [PubMed]

3. Hsu, P.D.; Lander, E.S.; Zhang, F. Development and applications of CRISPR-Cas9 for genome engineering. Cell 2014, 157, 1262-1278. [CrossRef] [PubMed]

4. Zlobin, N.E.; Lebedeva, M.V.; Taranov, V.V. CRISPR/Cas9 genome editing through in planta transformation. Crit. Rev. Biotechnol. 2020, 40, 153-168. [CrossRef] [PubMed]

5. Anami, S.; Njuguna, E.; Coussens, G.; Aesaert, S.; Van Lijsebettens, M. Higher plant transformation: Principles and molecular tools. Int. J. Dev. Biol. 2013, 57, 483-494. [CrossRef] [PubMed]

6. Tzfira, T.; Citovsky, V. Agrobacterium-mediated genetic transformation of plants: Biology and biotechnology. Curr. Opin. Biotechnol. 2006, 17, 147-154. [CrossRef]

7. Kapila, J.; De Rycke, R.; van Montagu, M.; Angenon, G. An Agrobacterium-mediated transient gene expression system for intact leaves. Plant Sci. 1997, 122, 101-108. [CrossRef]

8. Klein, T.M.; Wolf, E.D.; Sanford, J.C. High-velocity microprojectiles for delivering nucleic acids into living cells. Nature 1987, 327, 70-73. [CrossRef]

9. Paszkowski, J.; Shillito, R.D.; Saul, M.; Mandák, V.; Hohn, T.; Hohn, B.; Potrykus, I. Direct gene transfer to plants. EMBO J. 1984, 3, 2717-2722. [CrossRef]

10. D'Halluin, K.; Bonne, E.; Bossut, M.; De Beuckeleer, M.; Leemans, J. Transgenic maize plants by tissue electroporation. Plant Cell 1992, 4, 1495-1505.

11. De la Peña, A.; Lörz, H.; Schell, J. Transgenic rye plants obtained by injecting DNA into young floral tillers. Nature 1987, 325, 274-276. [CrossRef]

12. Krens, F.A.; Molendijk, L.; Wullems, G.J.; Schilperoort, R.A. In vitro transformation of plant protoplasts with Ti-plasmid DNA. Nature 1982, 296, 72-74. [CrossRef]

13. Clough, S.J.; Bent, A.F. Floral dip: A simplified method for Agrobacterium-mediated transformation of Arabidopsis thaliana. Plant J. 1998, 16, 735-743. [CrossRef]

14. Sandhya, D.; Jogam, P.; Allini, V.R.; Abbagani, S.; Alok, A. The present and potential future methods for delivering CRISPR/Cas9 components in plants. J. Genet. Eng. Biotechnol. 2020, 18, 1-11. [CrossRef]

15. Guidarelli, M.; Baraldi, E. Transient transformation meets gene function discovery: The strawberry fruit case. Front. Plant Sci. 2015, 6, 444. [CrossRef]

16. Twyman, R.M.; Kohli, A.; Stoger, E.; Christou, P. Foreign DNA: Integration and Expression in Transgenic Plants. In Genetic Engineering: Principles and Methods; Setlow, J.K., Ed.; Springer: Boston, MA, USA, 2002; Volume 24, pp. 107-136. 
17. Chhikara, S.; Chaudhary, D.; Yadav, M.; Sainger, M.; Jaiwal, P.K. A non-tissue culture approach for developing transgenic Brassica juncea L. plants with Agrobacterium tumefaciens. In Vitro Cell Dev. Biol. Plant 2012, 48, 7-14. [CrossRef]

18. Jones, H.D. Future of breeding by genome editing is in the hands of regulators. GM Crops Food 2015, 6, 223-232. [CrossRef] [PubMed]

19. Ashraf, A.; Rahman, A. CRISPR/Cas9 and Biosafety Issues. In Conference: Workshop Hand Book for 1st National Conference on CRISPR-Cas9 Genome Editing Technology; 2017; pp. 1-10. Available online: https:/ /www.researchgate.net/publication/33355745 6_CRISPRCas9_and_Biosafety_Issues (accessed on 10 September 2021).

20. Lee, M.W.; Yang, Y. Transient Expression Assay by Agroinfiltration of Leaves. Methods Mol. Biol. 2006, 323, 225-229. [CrossRef]

21. González, M.N.; Massa, G.A.; Andersson, M.; Andrea, C.; Oneto, D.; Turesson, H.; Storani, L.; Olsson, N.; Fält, A.S.; Hofvander, P.; et al. Comparative potato genome editing: Agrobacterium tumefaciens-mediated transformation and protoplasts transfection delivery of CRISPR/Cas9 components directed to StPPO2 gene. Plant Cell Tiss. Organ Cult. 2021, 145, 291-305. [CrossRef]

22. Zhang, Z.; Mao, Y.; Ha, S.; Liu, W.; Botella, J.R.; Zhu, J.K. A multiplex CRISPR/Cas9 platform for fast and efficient editing of multiple genes in Arabidopsis. Plant Cell Rep. 2016, 35, 1519-1533. [CrossRef] [PubMed]

23. Kim, H.; Choi, J.; Won, K.H. A stable DNA-free screening system for CRISPR/RNPs-mediated gene editing in hot and sweet cultivars of Capsicum annuum. BMC Plant Biol. 2020, 20, 449. [CrossRef]

24. Malzahn, A.; Lowder, L.; Qi, Y. Plant genome editing with TALEN and CRISPR. Cell Biosci. 2017, 7, 21. [CrossRef]

25. Donini, M.; Marusic, C. Current state-of-the-art in plant-based antibody production systems. Biotechnol. Lett. 2019, 41, 335-346. [CrossRef] [PubMed]

26. Jinek, M.; Chylinski, K.; Fonfara, I.; Hauer, M.; Doudna, J.A.; Charpentier, E. A programmable dual-RNA-guided DNA endonuclease in adaptive bacterial immunity. Science 2012, 337, 816-821. [CrossRef] [PubMed]

27. Zhang, Y.; Liang, Z.; Zong, Y.; Wang, Y.; Liu, J.; Chen, K.; Qiu, J.-L.; Gao, C. Efficient and transgene-free genome editing in wheat through transient expression of CRISPR/Cas9 DNA or RNA. Nat. Commun. 2016, 7, 12617. [CrossRef] [PubMed]

28. Liang, Z.; Chen, K.; Li, T.; Zhang, Y.; Wang, Y.; Zhao, Q.; Liu, J.; Zhang, H.; Liu, C.; Ran, Y.; et al. Efficient DNA-free genome editing of bread wheat using CRISPR/Cas9 ribonucleoprotein complexes. Nat. Commun. 2017, 8, 14261. [CrossRef] [PubMed]

29. Sheludko, Y.V. Agrobacterium-mediated transient expression as an approach to production of recombinant proteins in plants. Recent Pat. Biotechnol. 2008, 2, 198-208. [CrossRef]

30. Krenek, P.; Samajova, O.; Luptovciak, I.; Doskocilova, A.; Komis, G.; Samaj, J. Transient plant transformation mediated by Agrobacterium tumefaciens: Principles, methods and applications. Biotechnol. Adv. 2015, 33, 1024-1042. [CrossRef]

31. Lacroix, B.; Citovsky, V. The roles of bacterial and host plant factors in Agrobacterium mediated genetic transformation. Int. J. Dev. Biol. 2013, 57, 467-481. [CrossRef]

32. Chen, Q.; Lai, H.; Hurtado, J.; Stahnke, J.; Leuzinger, K.; Dent, M. Agroinfiltration as an effective and scalable strategy of gene delivery for production of pharmaceutical proteins. Adv. Tech. Biol. Med. 2013, 1, 103. [CrossRef]

33. Tyurin, A.A.; Suhorukova, A.V.; Kabardaeva, K.V.; Goldenkova-Pavlova, I.V. Transient gene expression is an effective experimental tool for the research into the fine mechanisms of plant gene function: Advantages, limitations, and solutions. Plants 2020, 9, 1187. [CrossRef]

34. Ramkumar, T.R.; Lenka, S.K.; Arya, S.; Bansal, K.C. A Short History and Perspectives on Plant Genetic Transformation. In Biolistic DNA Delivery in Plants; Methods in Molecular Biology; Rustgi, S., Luo, H., Eds.; Humana: New York, NY, USA, 2020 ; p. 2124. [CrossRef]

35. Low, L.Y.; Yang, S.K.; Andrew, K.D.X.; Ong-Abdullah, J.; Tan, N.P.; Lai, K.S. Transgenic plants: Gene constructs, vector and transformation method. In New Visions in Plant Science; Çelik, Ö., Ed.; Intech Open: London, UK, 2018; pp. 41-61.

36. Zambryski, P. Basic processes underlying Agrobacterium-mediated DNA transfer to plant cells. Annu. Rev. Genet. 1988, 22, 1-30. [CrossRef]

37. Christou, P.; Ford, T.L.; Kofron, M. Rice genetic engineering: A review. Trends Biotechnol. 1992, 10, 239-246. [CrossRef]

38. Crossway, A.; Oakes, J.V.; Irvine, J.M.; Ward, B.; Knauf, V.C.; Shewmaker, C.K. Integration of foreign DNA following microinjection of tobacco mesophyll protoplasts. Mol. Gen. Genet. 1986, 202, 179-185. [CrossRef]

39. Negrutiu, I.; Shillito, R.D.; Potrykus, I.; Biasini, G.; Sala, F. Hybrid genes in the analysis of transformation conditions. I. Setting up a simple method for direct gene transfer in plant protoplasts. Plant Mol. Biol. 1987, 8, 363-373. [CrossRef]

40. Datta, S.K.; Peterhans, A.; Datta, K.; Potrykus, I. Genetically engineered fertile Indica-rice plants recovered from protoplasts. Nat. Biotechnol. 1990, 8, 736-740. [CrossRef]

41. Shillito, R.D.; Saul, M.W.; Paszkowski, J.; Muller, M.; Potrykus, I. High efficiency direct gene transfer to plants. Nat. Biotechnol. 1985, 3, 1099-1103. [CrossRef]

42. Fromm, M.E.; Taylor, L.P.; Walbot, V. Stable transformation of maize after gene-transfer by electroporation. Nature 1986, 319, 791-793. [CrossRef] [PubMed]

43. Frame, B.R.; Drayton, P.R.; Bagnall, S.V.; Lewnau, C.J.; Bullock, W.P.; Wilson, H.M.; Dunwell, J.M.; Thompson, J.A.; Wang, K. Production of fertile transgenic maize plants by silicon-carbide whisker-mediated transformation. Plant J. 1994, 6, 941-948. [CrossRef]

44. Koncz, C.; Németh, K.; Rédei, G.P.; Schell, J. Homologous recombination and gene silencing in plants. In Homology Recognition during T-DNA Integration into the Plant Genome; Springer: Berlin/Heidelberg, Germany, 1994; pp. 167-189. 
45. Pawlowski, W.P.; Somers, D.A. Transgene inheritance in plants genetically engineered by microprojectile bombardment. Mol. Biotechnol. 1996, 6, 17-30. [CrossRef]

46. Hansen, G.; Shillito, R.D.; Chilton, M.D. T-strand integration in maize protoplasts after codelivery of a T-DNA substrate and virulence genes. Proc. Natl. Acad. Sci. USA 1997, 94, 11726-11730. [CrossRef] [PubMed]

47. Enríquez-Obregón, G.A.; Vázquez-Padrón, R.I.; Prieto-Samsonov, D.L.; De la Riva, G.A.; Selman-Housein, G. Herbicide-resistant sugarcane (Saccharum officinarum L.) plants by Agrobacterium mediated transformation. Planta 1998, 206, 20-27. [CrossRef]

48. Shou, H.; Frame, B.R.; Whitham, S.A.; Wang, K. Assessment of transgenic maize events produced by particle bombardment or Agrobacterium mediated transformation. Mol. Breed. 2004, 13, 201-208. [CrossRef]

49. Travella, S.; Ross, S.M.; Harden, J.; Everett, C.; Snape, J.W.; Harwood, W.A. A comparison of transgenic barley lines produced by particle bombardment and Agrobacterium mediated techniques. Plant Cell Rep. 2005, 23, 780-789. [CrossRef] [PubMed]

50. Zhang, Y.; Yin, X.; Yang, A.; Li, G.; Zhang, J. Stability of inheritance of transgenes in maize (Zea mays L.) lines produced using different transformation methods. Euphytica 2005, 144, 11-22. [CrossRef]

51. Gao, C.; Long, D.; Lenk, I.; Nielsen, K.K. Comparative analysis of transgenic tall fescue (Festuca arundinacea Schreb.) plants obtained by Agrobacterium mediated transformation and particle bombardment. Plant Cell Rep. 2008, 27, 1601-1609. [CrossRef]

52. Hwang, H.H.; Yu, M.; Lai, E.M. Agrobacterium-mediated plant transformation: Biology and applications. Arab. Book 2017, 15, e0186. [CrossRef] [PubMed]

53. McIntosh, K.B.; Hulm, J.L.; Young, L.W.; Bonham-Smith, P.C. A rapid Agrobacterium-mediated Arabidopsis thaliana transient assay system. Plant Mol. Biol. Rep. 2004, 22, 53-61. [CrossRef]

54. Sheng, J.; Citovsky, V. Agrobacterium-plant cell interaction: Have virulence proteins, will travel. Plant Cell 1996, 8, 1699-1710.

55. Horsch, R.B.; Fry, J.E.; Hoffmann, N.L.; Eïchholtz, D.; Rogers, S.G.; Fraley, R.T. A simple and general method for transferring genes into plants. Science 1985, 227, 1229-1231.

56. Chilton, M.D.; Drummond, M.H.; Merlo, D.J.; Sciaky, D.; Montoya, A.L.; Gordon, M.P.; Nester, E.W. Stable incorporation of plasmid DNA into higher plant cells: The molecular basis of crown gall tumorigenesis. Cell 1977, 11, 263-271. [CrossRef]

57. De Cleene, M.; De Ley, J. The host range of crown gall. Bot. Rev. 1976, 42, 389-466. [CrossRef]

58. Li, W.; Guo, G.; Zheng, G. Agrobacterium-mediated transformation: State of the art and future prospect. Chin. Sci. Bull. 2000, 45, 1537-1546. [CrossRef]

59. Bundock, P.; den Dulk-Ras, A.; Beijersbergen, A.; Hooykaas, P.J. Trans-kingdom T-DNA transfer from Agrobacterium tumefaciens to Saccharomyces cerevisiae. EMBO J. 1995, 14, 3206-3214. [CrossRef] [PubMed]

60. Bundock, P.; Mroczek, K.; Winkler, A.A.; Steensma, H.Y.; Hooykaas, P.J.J. T-DNA from Agrobacterium tumefaciens as an efficient tool for gene targeting in Kluyveromyces lactis. Mol. Gen. Genet. 1999, 261, 115-121. [CrossRef] [PubMed]

61. Piers, K.L.; Heath, J.D.; Liang, X.; Stephens, K.M.; Nester, E.W. Agrobacterium tumefaciens mediated transformation of yeast. Proc. Natl. Acad. Sci. USA 1996, 93, 1613-1618. [CrossRef] [PubMed]

62. De Groot, M.J.A.; Bundock, P.; Hooykaas, P.J.J.; Beijersbergen, A.G.M. Agrobacterium tumefaciens mediated transformation of filamentous fungi. Nat. Biotechnol. 1998, 16, 839-842. [CrossRef]

63. Kunik, T.; Tzfira, T.; Kapulnik, Y.; Gafni, Y.; Dingwall, C.; Citovsky, V. Genetic transformation of HeLa cells by Agrobacterium. Proc. Natl. Acad. Sci. USA 2001, 98, 1871-1876. [CrossRef]

64. Kelly, B.A.; Kado, C.I. Agrobacterium mediated T-DNA transfer and integration into the chromosome of Streptomyces lividans. Mol. Plant Pathol. 2002, 3, 125-134. [CrossRef]

65. Hooykaas, P.J.J. Transformation mediated by Agrobacterium tumefaciens. In Advances in Fungal Biotechnology for Industry, Agriculture, and Medicine; Tkacz, J.S., Lange, L., Eds.; Springer: Boston, MA, USA, 2004; pp. 41-65.

66. Kumar, S.V.; Misquitta, R.W.; Reddy, V.S.; Rao, B.J.; Rajam, M.V. Genetic transformation of the green alga-Chlamydomonas reinhardtii by Agrobacterium tumefaciens. Plant Sci. 2004, 166, 731-738. [CrossRef]

67. Pelczar, P.; Kalck, V.; Gomez, D.; Hohn, B. Agrobacterium proteins VirD2 and VirE2 mediate precise integration of synthetic TDNA complexes in mammalian cells. EMBO Rep. 2004, 5, 632-637. [CrossRef]

68. Michielse, C.B.; Hooykaas, P.J.J.; van den Hondel, C.A.; Ram, A.F. Agrobacterium mediated transformation as a tool for functional genomics in fungi. Curr. Genet. 2005, 48, 1-17. [CrossRef]

69. Bulgakov, V.P.; Kiselev, K.V.; Yakovlev, K.V.; Zhuravlev, Y.N.; Gontcharov, A.A.; Odintsova, N.A. Agrobacterium mediated transformation of sea urchin embryos. Biotechnol. J. 2006, 1, 454-461. [CrossRef]

70. Lacroix, B.; Li, J.; Tzfira, T.; Citovsky, V. Will you let me use your nucleus? How Agrobacterium gets its T-DNA expressed in the host plant cell. Can. J. Physiol. Pharmacol. 2006, 84, 333-345. [CrossRef] [PubMed]

71. Thomashow, M.; Panagopoulos, C.; Gordon, M.; Nester, E.W. Host range of Agrobacterium tumefaciens is determined by the Ti plasmid. Nature 1980, 283, 794-796. [CrossRef]

72. Herrera-Estrella, L.; Simpson, J.; Martinez-Trujillo, M. Transgenic plants: An historical perspective. Methods Mol. Biol. 2005, 286, 3-32. [PubMed]

73. Draper, J.; Scott, R.; Hamill, J. Transformation of dicotyledonous plant cells using the Ti plasmid of Agrobacterium tumefaciens and the Ri plasmid of A. rhizogenes. In Plant Genetic Transformation and Gene Expression: A Laboratory Manual; Draper, J., Scott, R., Armitage, P., Walden, R., Eds.; Blackwell Scientific Publishers: Oxford, UK, 1988; pp. 69-160.

74. Tinland, B. The integration of T-DNA into plant genomes. Trends Plant Sci. 1996, 1, 178-184. [CrossRef] 
75. Bhattacharya, A.; Sood, P.; Citovsky, V. The roles of plant phenolics in defence and communication during Agrobacterium and Rhizobium infection. Mol. Plant Pathol. 2010, 11, 705-719. [CrossRef] [PubMed]

76. Gelvin, S.B. Plant proteins involved in Agrobacterium mediated genetic transformation. Annu. Rev. Phytopathol. 2010, 48, 45-68. [CrossRef] [PubMed]

77. Gelvin, S.B. Traversing the cell: Agrobacterium T-DNA's journey to the host genome. Front. Plant Sci. 2012, 3, 52. [CrossRef]

78. Pitzschke, A. Agrobacterium infection and plant defense-transformation success hangs by a thread. Front. Plant Sci. 2013, 4, 519. [CrossRef] [PubMed]

79. Christie, P.J.; Whitaker, N.; González-Rivera, C. Mechanism and structure of the bacterial type IV secretion systems. Biochim. Biophys. Acta Mol. Cell Res. 2014, 1843, 1578-1591. [CrossRef]

80. Hwang, H.H.; Liu, Y.T.; Huang, S.C.; Tung, C.Y.; Huang, F.C.; Tsai, Y.L.; Cheng, T.F.; Lai, E.M. Overexpression of the HspL promotes Agrobacterium tumefaciens virulence in Arabidopsis under heat shock conditions. Phytopathology 2015, 105, 160-168. [CrossRef]

81. Nonaka, S.; Someya, T.; Kadota, Y.; Nakamura, K.; Ezura, H. Super-Agrobacterium ver. 4: Improving the transformation frequencies and genetic engineering possibilities for crop plants. Front. Plant Sci. 2019, 10, 1204. [CrossRef]

82. Hoshikawa, K.; Fujita, S.; Renhu, N.; Ezura, K.; Yamamoto, T.; Nonaka, S.; Ezura, H.; Miura, K. Efficient transient protein expression in tomato cultivars and wild species using agroinfiltration-mediated high expression system. Plant Cell Rep. 2019, 38, 75-84. [CrossRef]

83. Knoch, E.; Sugawara, S.; Mori, T.; Poulsen, C.; Fukushima, A.; Harholt, J.; Fujimoto, Y.; Umemoto, N.; Saito, K. Third DWF1 paralog in Solanaceae, sterol $\Delta 24$-isomerase, branches withanolide biosynthesis from the general phytosterol pathway. Proc. Natl. Acad. Sci. USA 2019, 115, E8096-E8103. [CrossRef]

84. Bent, A. Arabidopsis thaliana Floral Dip Transformation Method. In Agrobacterium Protocols; Methods in Molecular, Biology; Wang, K., Ed.; Humana Press: New York, NY, USA, 2006; Volume 343.

85. Gelvin, S.B. Agrobacterium Transformation of Arabidopsis thaliana Roots. In Agrobacterium Protocols; Methods in Molecular, Biology; Wang, K., Ed.; Humana Press: New York, NY, USA, 2006; Volume 343.

86. Tague, B.W.; Mantis, J. In Planta Agrobacterium-Mediated transformation by vacuum infiltration. In Arabidopsis Protocols; Methods in Molecular, Biology ${ }^{\mathrm{TM}}$; Salinas, J., Sanchez-Serrano, J.J., Eds.; Humana Press: New York, NY, USA, 2006; Volume 323.

87. Rivero, L.; Scholl, R.; Holomuzki, N.; Crist, D.; Grotewold, E.; Brkljacic, J. Handling Arabidopsis Plants: Growth, Preservation of Seeds, Transformation, and Genetic Crosses. In Arabidopsis Protocols; Methods in Molecular Biology (Methods and, Protocols); Sanchez-Serrano, J., Salinas, J., Eds.; Humana Press: Totowa, NJ, USA, 2014.

88. Wroblewski, T.; Tomczak, A.; Michelmore, R. Optimization of Agrobacterium mediated transient assays of gene expression in lettuce, tomato and Arabidopsis. Plant Biotechnol. J. 2005, 3, 259-273. [CrossRef] [PubMed]

89. Marion, J.; Bach, L.; Bellec, Y.; Meyer, C.; Gissot, L.; Faure, J.D. Systematic analysis of protein subcellular localization and interaction using high-throughput transient transformation of Arabidopsis seedlings. Plant J. 2008, 56, 169-179. [CrossRef]

90. Jones, H.D.; Doherty, A.; Sparks, C.A. Transient transformation of plants. Methods Mol. Biol. 2009, 513, 131-152.

91. Kim, M.J.; Baek, K.; Park, C.M. Optimization of conditions for transient Agrobacterium mediated gene expression assays in Arabidopsis. Plant Cell Rep. 2009, 28, 1159-1167. [CrossRef] [PubMed]

92. Li, J.F.; Park, E.; von Arnim, A.G.; Nebenfuhr, A. The FAST technique: A simplified Agrobacterium-based transformation method for transient gene expression analysis in seedlings of Arabidopsis and other plant species. Plant Methods 2009, 5, 6. [CrossRef]

93. Tsuda, K.; Qi, Y.; Nguyen, L.V.; Bethke, G.; Tsuda, Y.; Glazebrook, J.; Katagiri, F. An efficient Agrobacterium-mediated transient transformation of Arabidopsis. Plant J. 2012, 69, 713-719. [CrossRef]

94. Wu, H.Y.; Liu, K.H.; Wang, Y.C.; Wu, J.F.; Chiu, W.L.; Chen, C.Y.; Wu, S.H.; Sheen, J.; Lai, E.M. AGROBEST: An efficient Agrobacterium mediated transient expression method for versatile gene function analyses in Arabidopsis seedlings. Plant Methods 2014, 10, 19. [CrossRef] [PubMed]

95. Janssen, B.J.; Gardner, R.C. Localized transient expression of GUS in leaf discs following cocultivation with Agrobacterium. Plant Mol. Biol. 1989, 14, 61-72. [CrossRef] [PubMed]

96. Zhang, N.; Roberts, H.M.; Eck, J.V.; Martin, G.B. Generation and molecular characterization of CRISPR/Cas9-induced mutations in 63 immunity-associated genes in tomato reveals specificity and a range of gene modifications. Front. Plant Sci. 2020, 11, 10. [CrossRef] [PubMed]

97. Cao, D.V.; Pamplona, R.S.; Kim, J.; Oh, Y.K.; Cho, S.K.; Ahn, J.; Yang, S.W.; Riu, K.Z.; Boo, K.H. Optimization of Agrobacteriummediated transient expression of heterologous genes in spinach. Plant Biotechnol. Rep. 2017, 11, 397-405. [CrossRef]

98. Zhao, H.; Tan, Z.; Wen, X.; Wang, Y. An improved syringe agroinfiltration protocol to enhance transformation efficiency by combinative use of 5-azacytidine, ascorbate acid and tween-20. Plants 2017, 6, 9. [CrossRef] [PubMed]

99. Heenatigala, P.P.M.; Yang, J.J.; Bishopp, A.; Sun, Z.L.; Li, G.J.; Kumar, S.; Hu, S.; Wu, Z.; Lin, W.; Yao, L.; et al. Development of efficient protocols for stable and transient gene transformation for Wolffia globosa using Agrobacterium. Front. Chem. 2018, 6, 227. [CrossRef]

100. Ma, T.; Li, Z.; Wang, S. Production of bioactive recombinant reteplase by virus-based transient expression system in Nicotiana benthamiana. Front. Plant Sci. 2019, 10, 1225. [CrossRef] [PubMed]

101. Garabagi, F.; McLean, M.D.; Hall, J.C. Transient and stable expression of antibodies in Nicotiana species. Methods Mol. Biol. 2012, $907,389-408$. 
102. Sánchez-Álvarez, A.; Ruíz-López, N.; Moreno-Pérez, A.J.; Martínez-Force, E.; Garcés, R.; Salas, J.J. Agrobacterium-mediated transient gene expression in developing Ricinus communis seeds: A first step in making the castor oil plant a chemical biofactory. Front. Plant Sci. 2019, 10, 1410. [CrossRef] [PubMed]

103. Sainsbury, F.; Lomonossoff, G.P. Transient expressions of synthetic biology in plants. Curr. Opin. Plant Biol. 2014, 19, 1-7. [CrossRef] [PubMed]

104. Osakabe, Y.; Osakabe, K. Genome editing to improve abiotic stress responses in plants. Prog. Mol. Biol. Transl. Sci. 2017, 149, 99-109. [PubMed]

105. Gleba, Y.; Klimyu, V.; Marillonnet, S. Magnifection-A new platform for expressing recombinant vaccines in plants. Vaccine 2005, 23, 2047-2048. [CrossRef] [PubMed]

106. Gleba, Y.; Klimyuk, V.; Marillonnet, S. Viral vectors for the expression of proteins in plants. Curr. Opin. Biotechnol. 2007, 18, 134-141. [CrossRef]

107. Potrykus, I. Gene transfer to plants: Assessment of published approaches and results. Annu. Rev. Plant Biol. 1991, 42, 205-225. [CrossRef]

108. Dai, S.; Zheng, P.; Marmey, P.; Zhang, S.; Tian, W.; Chen, S.; Beachy, R.N.; Fauquet, C. Comparative analysis of transgenic rice plants obtained by Agrobacterium mediated transformation and particle bombardment. Mol. Breed. 2001, 7, 25-33. [CrossRef]

109. Zheng, L.; Liu, G.; Meng, X.; Li, Y.; Wang, Y. A versatile Agrobacterium-mediated transient gene expression system for herbaceous plants and trees. Biochem. Genet. 2012, 50, 761-769. [CrossRef]

110. Burman, N.; Chandran, D.; Khurana, J.P. A rapid and highly efficient method for transient gene expression in rice plants. Front. Plant Sci. 2020, 11, 584011. [CrossRef]

111. Fischer, R.; Vaquero-Martin, C.; Sack, M.; Drossard, J.; Emans, N.; Commandeur, U. Towards molecular farming in the future: Transient protein expression in plants. Biotechnol. Appl. Biochem. 1999, 30, 113-116.

112. Sparkes, I.A.; Runions, J.; Kearns, A.; Hawes, C. Rapid, transient expression of fluorescent fusion proteins in tobacco plants and generation of stably transformed plants. Nat. Protoc. 2006, 1, 2019-2025. [CrossRef]

113. Zhou, D.D.; Yu, J.N. The progress of establishing transient expression system in plant cell. Chin. Agric. Sci. Bull. 2013, 29, 151-156.

114. Liu, S.; Ma, J.; Liu, H.; Guo, Y.; Li, W.; Niu, S. An efficient system for Agrobacterium-mediated transient transformation in Pinus tabuliformis. Plant Methods 2020, 16, 52. [CrossRef] [PubMed]

115. Xia, P.; Hu, W.; Liang, T.; Yang, D.; Liang, Z. An attempt to establish an Agrobacterium-mediated transient expression system in medicinal plants. Protoplasma 2020, 257, 1497-1505. [CrossRef] [PubMed]

116. Kusnadi, A.R.; Nikolov, Z.L.; Howard, J.A. Production of recombinant proteins in transgenic plants: Practical considerations. Biotechnol. Bioeng. 1997, 56, 473-484. [CrossRef]

117. Marsian, J.; Lomonossoff, G.P. Molecular pharming-VLPs made in plants. Curr. Opin. Biotechnol. 2016, 37, 201-206. [CrossRef]

118. Norkunas, K.; Harding, R.; Dale, J.; Dugdale, B. Improving agroinfiltration-based transient gene expression in Nicotiana benthamiana. Plant Methods 2018, 14, 71. [CrossRef]

119. Yuasa, T.; Sugiki, M.; Watanabe, Y. Activation of SIPK in response to UV-C irradiation, utility of a glutathione-S transferase-tagged plant MAP kinase by transient expression with agroinfiltration. Plant Biotechnol. 2005, 22, 7-12. [CrossRef]

120. Joh, L.D.; Wroblewski, T.; Ewing, N.N.; VanderGheynst, J.S. High-level transient expression of recombinant protein in lettuce. Biotechnol. Bioeng. 2005, 91, 861-871. [CrossRef]

121. Rico, A.; Bennett, M.H.; Forcat, S.; Huang, W.E.; Preston, G.M. Agroinfiltration reduces ABA levels and suppresses Pseudomonas syringae-elicited salicylic acid production in Nicotiana tabacum. PLoS ONE 2010, 5, e8977. [CrossRef]

122. Hoffmann, T.; Kalinowski, G.; Schwab, W. RNAi-induced silencing of gene expression in strawberry fruit $($ Fragaria $\times$ ananassa) by agroinfiltration: A rapid assay for gene function analysis. Plant J. 2006, 48, 818-826. [CrossRef]

123. Menassa, R.; Ahmad, A.; Joensuu, J.J. Transient expression using agroinfiltration and its applications in molecular farming. In Molecular Farming in Plants: Recent Advances and Future Prospects; Wang, A., Ma, S., Eds.; Springer: Berlin/Heidelberg, Germany, 2012. [CrossRef]

124. Tan, L.W.; Rahman, Z.A.; Goh, H.H.; Hwang, D.; Ismanizan, I.; Zamri, Z. Production of transgenic rice (indica cv. MR219) overexpressing Abp57 gene through Agrobacterium-mediated transformation. Sains. Malays. 2017, 46, 703-711. [CrossRef]

125. Wang, H.; Jiang, L. Transient expression and analysis of fluorescent reporter proteins in plant pollen tubes. Nat. Protoc. 2011, 6, 419-426. [CrossRef]

126. Del Toro, F.; Tenllado, F.; Chung, B.N.; Canto, T.A. Procedure for the transient expression of genes by agroinfiltration above the permissive threshold to study temperature-sensitive processes in plant-pathogen interactions. Mol. Plant Pathol. 2014, 15, 848-857. [CrossRef]

127. Voinnet, O.; Rivas, S.; Mestre, P.; Baulcombe, D. An enhanced transient expression system in plants based on suppression of gene silencing by the 19 protein of tomato bushy stunt virus. Plant J. 2003, 33, 949-956. [CrossRef] [PubMed]

128. Liu, K.; Yang, Q.; Yang, T.; Wu, Y.; Wang, G.; Yang, F.; Wang, R.; Lin, X.; Li, G. Development of Agrobacterium-mediated transient expression system in Caragana intermedia and characterization of CiDREB1C in stress response. BMC Plant Biol. 2019, 19, 237. [CrossRef] [PubMed]

129. Chen, Q.; Lai, H. Gene delivery into plant cells for recombinant protein production. BioMed Res. Int. 2015, 2015, 932161. [CrossRef] [PubMed] 
130. Shoji, Y.; Chichester, J.A.; Bi, H.; Musiychuk, K.; de la Rosa, P.; Goldschmidt, L.; Horsey, A.; Ugulava, N.; Palmer, G.A.; Mett, V.; et al. Plant-expressed HA as a seasonal influenza vaccine candidate. Vaccine 2008, 26, 2930-2934. [CrossRef]

131. Ma, J.; Xiang, H.; Donnelly, D.J.; Meng, F.-R.; Xu, H.; Durnford, D.; Li, X.-Q. Genome editing in potato plants by agrobacteriummediated transient expression of transcription activator-like effector nucleases. Plant Biotechnol. Rep. 2017, 11, 249-258. [CrossRef]

132. Krishnan, V.; Jose, J.; Jolly, M.; Vinutha, T.; Kumar, R.; Manickavasagam, M.; Praveen, S.; Sachdev, A. 'AGRODATE': A rapid Agrobacterium-mediated transient expression tool for gene function analysis in leaf discs. J. Plant Biochem. Biotechnol. 2019, 29, 294-304. [CrossRef]

133. Fraley, R.; Horsch, R.; Matzke, A.; Chilton, M.D.; Chilton, W.S.; Sanders, P.R. In vitro transformation of petunia cells by an improved method of co-cultivation with A. tumefaciens strains. Plant Mol. Biol. 1984, 3, 371-378. [CrossRef]

134. Horsch, R.B.; Klee, H.J. Rapid assay of foreign gene expression in leaf disc transformed by Agrobacterium tumefaciens: Role of T-DNA borders in the transfer process. Proc. Natl. Acad. Sci. USA 1986, 83, 4428-4432. [CrossRef]

135. Vaghchhipawala, Z.; Rojas, C.M.; Senthil-Kumar, M.; Mysore, K.S. Agroinoculation and Agroinfiltration: Simple Tools for Complex Gene Function Analyses. In Plant Reverse Genetics; Methods in Molecular Biology (Methods and, Protocols); Pereira, A., Ed.; Humana Press: Totowa, NJ, USA, 2011; Volume 678.

136. Jia, H.; Liao, M.; Verbelen, J.P.; Vissenberg, K. Direct creation of marker-free tobacco plants from agroinfiltrated leaf discs. Plant Cell Rep. 2007, 26, 1961-1965. [CrossRef]

137. Orzaez, D.; Mirabel, S.; Wieland, W.H.; Granell, A. Agroinjection of tomato fruits. A tool for rapid functional analysis of transgenes directly in fruit. Plant Physiol. 2006, 140, 3-11. [CrossRef]

138. Qian, W.; Yu, C.; Qin, H.; Liu, X.; Zhang, A.; Johansen, I.E.; Wang, D. Molecular and functional analysis of phosphomannomutase (PMM) from higher plants and genetic evidence for the involvement of PMM in ascorbic acid biosynthesis in Arabidopsis and Nicotiana benthamiana. Plant J. 2007, 49, 399-413. [CrossRef]

139. Zottini, M.; Barizza, E.; Costa, A.; Formentin, E.; Ruberti, C.; Carimi, F.; Schiavo, F.L. Agroinfiltration of grapevine leaves for fast transient assays of gene expression and for long-term production of stable transformed cells. Plant Cell Rep. 2008, 27, 845-853. [CrossRef]

140. Matsuo, K.; Fukuzawa, N.; Matsumura, T. A simple agroinfiltration method for transient gene expression in plant leaf discs. J. Biosci. Bioeng. 2016, 122, 351-356. [CrossRef] [PubMed]

141. Xu, K.; Huang, X.; Wu, M.; Wang, Y.; Chang, Y.; Liu, K.; Zhang, J.; Zhang, Y.; Zhang, F.; Yi, L.; et al. A rapid, highly efficient and economical method of Agrobacterium-mediated In Planta transient transformation in living onion epidermis. PLoS ONE 2014, 9, e83556. [CrossRef] [PubMed]

142. Shin, D.I.; Park, H.S. Transient expression in chinese cabbage by hydrogen peroxide-aided agroinfiltration. Agric. Chem. Biotechnol. 2005, 48, 229-230.

143. Naji-Talakar, S. Plant-derived biopharmaceuticals: Overview and success of agroinfiltration. Trends Capstone 2017, 2, 1-12.

144. Juranić, M.; Nagahatenna, D.S.K.; Salinas-Gamboa, R.; Hand, M.L.; Sánchez-León, N.; Leong, W.H.; How, T.; Bazanova, N.; Spriggs, A.; Vielle-Calzada, J.-P.; et al. A detached leaf assay for testing transient gene expression and gene editing in cowpea (Vigna unguiculata [L.] Walp.). Plant Methods 2020, 16, 88. [CrossRef] [PubMed]

145. Amoah, B.K.; Wu, H.; Sparks, C.; Jones, H.D. Factors influencing Agrobacterium-mediated transient expression of uidA in wheat inflorescence tissue. J. Exp. Bot. 2001, 52, 1135-1142. [CrossRef] [PubMed]

146. Mondal, T.; Bhattacharya, A.; Ahuja, P.; Chand, P. Transgenic tea [Camellia sinensis (L.) O. Kuntze cv. Kangra Jat] plants obtained by Agrobacterium-mediated transformation of somatic embryos. Plant Cell Rep. 2001, 20, 712-720. [CrossRef]

147. Dong, J.Z.; McHughen, A. An improved procedure for production of transgenic flax plants using Agrobacterium tumefaciens. Plant Sci. 1993, 88, 61-71. [CrossRef]

148. Matsuda, D.; Dreher, T.W. The tRNA-like structure of Turnip yellow mosaic virus RNA is a $3^{\prime}$-translational enhancer. Virology 2004, 321, 36-46. [CrossRef]

149. Sepahdoost, S.; Haghighi, H.; Sohi, H.H.; Jourabchi, E.; Ghorbanli, M. Agroinfiltration of Human Growth Hormone in Medicago sativa and Trifolium Alexanderium Leaves; National Congress of Biotechnology of Iran; Iranian Biotechnology Association: Trieste, Italy, 2005; Volume 4.

150. Vargas-Guevara, C.; Vargas-Segura, C.; Villalta-Villalobos, J.; Pereira, L.F.P.; Gatica-Arias, A. A simple and efficient agroinfiltration method in coffee leaves (Coffea arabica L.): Assessment of factors affecting transgene expression. 3 Biotech 2018, 8, 471. [CrossRef]

151. Ahlquist, P. RNA-dependent RNA polymerases, viruses, and RNA silencing. Science 2002, 296, 1270-1273. [CrossRef]

152. Fischer, R.; Stoger, E.; Schillberg, S.; Christou, P.; Twyman, R.M. Plant-based production of biopharmaceuticals. Curr. Opin. Plant Biol. 2004, 7, 152-158. [CrossRef]

153. Delgadillo, M.O.; Saenz, P.; Salvador, B.; García, J.A.; Simón-Mateo, C. Human influenza virus NS1 protein enhances viral pathogenicity and acts as an RNA silencing suppressor in plants. J. Gen. Virol. 2004, 85, 993-999. [CrossRef]

154. Han, L.; Zhang, L.; Liu, J.; Li, H.; Wang, Y.; Hasi, A. Transient expression of optimized and synthesized nattokinase gene in melon (Cucumis melo L.) fruit by agroinfiltration. Plant Biotechnol. 2015, 15, 0430a. [CrossRef]

155. King, J.L.; Finer, J.J.; McHale, L.K. Development and optimization of agroinfiltration for soybean. Plant Cell Rep. 2015, 34, 133-140. [CrossRef] [PubMed]

156. Wydro, M.; Kozubek, E.; Lehmann, P. Optimization of transient Agrobacterium-mediated gene expression system in leaves of Nicotiana benthamiana. Acta Biochim Pol. 2006, 53, 289-298. [CrossRef] [PubMed] 
157. Arzola, L.; Chen, J.; Rattanaporn, K.; Maclean, J.M.; McDonald, K.A. Transient co-expression of post-transcriptional gene silencing suppressors for increased In Planta expression of a recombinant anthrax receptor fusion protein. Int. J. Mol. Sci. 2011, 12, 4975-4990. [CrossRef] [PubMed]

158. Zhang, Z.; Fradin, E.; de Jonge, R.; van Esse, H.P.; Smit, P.; Liu, C.-M.; Thomma, B.P.H.J. Optimized agroinfiltration and virusinduced gene silencing to study Ve1-mediated Verticillium resistance in tobacco. Mol. Plant Microbe Interact. 2013, 26, 182-190. [CrossRef] [PubMed]

159. Bashandy, H.; Jalkanen, S.; Teeri, T.H. Within leaf variation is the largest source of variation in agroinfiltration of Nicotiana benthamiana. Plant Methods 2015, 11, 1. [CrossRef]

160. Patil, B.L.; Fauquet, C.M. Light intensity and temperature affect systemic spread of silencing signal in transient agroinfiltration studies. Mol. Plant Pathol. 2015, 16, 484-494. [CrossRef]

161. Fujiuchi, N.; Matsuda, R.; Matoba, N.; Fujiwara, K. Removal of bacterial suspension water occupying the intercellular space of detached leaves after agroinfiltration improves the yield of recombinant hemagglutinin in a Nicotiana benthamiana transient gene expression system. Biotechnol Bioeng. 2016, 113, 901-906. [CrossRef]

162. Hanittinan, O.; Oo, Y.; Chaotham, C.; Rattanapisit, K.; Shanmugaraj, B.; Phoolcharoen, W. Expression optimization, purification and in vitro characterization of human epidermal growth factor produced in Nicotiana benthamiana. Biotechnol. Rep. 2020, 28, e00524. [CrossRef] [PubMed]

163. Diamos, A.G.; Hunter, J.G.L.; Pardhe, M.D.; Rosenthal, S.H.; Sun, H.; Foster, B.C.; DiPalma, M.P.; Chen, Q.; Mason, H.S. High level production of monoclonal antibodies using an optimized plant expression system. Front. Bioeng. Biotechnol. $2020,7,472$. [CrossRef]

164. Heidari-Japelaghi, R.; Valizadeh, M.; Haddad, R.; Dorani-Uliaiea, E.; Jalali-Javaran, M. Production of bioactive human IFN- $\gamma$ protein by agroinfiltration in tobacco. Protein Expr. Purif. 2020, 173, 105616. [CrossRef]

165. Guy, E.; Boulain, H.; Aigu, Y.; Pennec, C.L.; Chawki, K.; Morlière, S.; Schädel, K.; Kunert, G.; Simon, J.-C.; Sugio, A. Optimization of agroinfiltration in Pisum sativum provides a new tool for studying the salivary protein functions in the pea aphid complex. Front Plant Sci. 2016, 7, 1171. [CrossRef] [PubMed]

166. Kokkirala, V.R.; Peng, Y.; Abbagani, S.; Zhu, Z.; Umate, P. Subcellular localization of proteins of Oryza sativa L. in the model tobacco and tomato plants. Plant Signal Behav. 2010, 5, 1336-1341. [CrossRef] [PubMed]

167. Deguchi, M.; Bogush, D.; Weeden, H.; Spuhler, Z.; Potlakayala, S.; Kondo, T.; Zhang, Z.J.; Rudrabhatla, S. Establishment and optimization of a hemp (Cannabis sativa L.) agroinfiltration system for gene expression and silencing studies. Sci. Rep. 2020, 10, 3504. [CrossRef]

168. Sung, H.P. In Vitro culture and transformation by agroinfiltration of lisianthus (Eustoma russellianus) pollen. J. Life Sci. 2004, 14, 1018-1022.

169. Hussein, G.M.; Abu El-Heba, G.A.; Abdou, S.M.; Abdallah, N.A. Optimization of transient gene expression system in Gerbera jamesonii petals. GM Crops Food 2013, 4, 50-57. [CrossRef] [PubMed]

170. Mani, T.; Manjula, S. Optimization of Agrobacterium-mediated transient gene expression and endogenous gene silencing in Piper colubrinum Link. by vacuum infiltration. Plant Cell Tiss. Organ Cult. 2011, 105, 113-119. [CrossRef]

171. Santos-Rosa, M.; Poutaraud, A.; Merdinoglu, D.; Mestre, P. Development of a transient expression system in grapevine via agro-infiltration. Plant Cell Rep. 2008, 27, 1053-1063. [CrossRef]

172. Faizal, A.; Geelen, D. Agroinfiltration of intact leaves as a method for the transient and stable transformation of saponin producing Maesa lanceolata. Plant Cell Rep. 2012, 31, 1517-1526. [CrossRef]

173. Chevreau, E.; Dousset, N.; Joffrion, C.; Richer, A.; Charrier, A.; Vergne, E. Agroinfiltration is a key factor to improve the efficiency of apple and pear transformation. Sci. Hortic. 2019, 251, 150-154. [CrossRef]

174. Abd-Aziz, N.; Tan, B.C.; Rejab, N.A.; Othman, R.Y.; Khalid, N. A new plant expression system for producing pharmaceutical proteins. Mol. Biotechnol. 2020, 62, 240-251. [CrossRef]

175. Sohi, H.H.; Jourabchi, E.; Khodabandeh, M. Transient expression of human growth hormone in potato (Solanum tuberosum), tobacco (Nicotiana tobacum) and lettuce (Lactuca sativa) leaves by agroinfiltration. Iranian J. Biotechnol. 2005, 3, $109-113$.

176. Koscianska, E.; Kalantidis, K.; Wypijewski, K.; Sadowski, J.; Tabler, M. Analysis of RNA silencing in agroinfiltrated leaves of Nicotiana benthamiana and Nicotiana tabacum. Plant Mol. Biol. 2005, 59, 647-661. [CrossRef]

177. Yamamoto, T.; Hoshikawa, K.; Ezura, K.; Okazawa, R.; Fujita, S.; Takaoka, M.; Mason, H.S.; Ezura, H.; Miura, K. Improvement of the transient expression system for production of recombinant proteins in plants. Sci. Rep. 2018, 8, 4755. [CrossRef] [PubMed]

178. Affandi, N.D.; Mostaffa, N.H.; Al-Idrus, A. Interactomics: Development of an efficient and improved Agrobacterium tumefaciensmediated transformation method for transient expression of heterologous protein in recalcitrant plant tissues in planta. Res. Square 2020. [CrossRef]

179. Belhaj, K.; Chaparro-Garcia, A.; Kamoun, S.; Nekrasov, V. Plant genome editing made easy: Targeted mutagenesis in model and crop plants using the CRISPR/Cas system. Plant Methods 2013, 9, 39. [CrossRef] [PubMed]

180. Fischer, R.; Emans, N. Molecular farming of pharmaceutical proteins. Transgenic Res. 2000, 9, 279-299. [CrossRef] [PubMed]

181. Song, G.; Yamaguchi, K. Efficient agroinfiltration-mediated transient GUS expression for assaying different promoters in rice. Plant Biotechnol. 2003, 20, 235-239. [CrossRef]

182. Coura, R.; Nardi, N. A role for adeno-associated viral vectors in gene therapy. Genet. Mol. Biol. 2008, 31, 1-11. [CrossRef] 
183. Soyars, C.L.; Peterson, B.A.; Burr, C.A.; Nimchuk, Z.L. Cutting edge genetics: CRISPR/Cas9 editing of plant genomes. Plant Cell Physiol. 2018, 59, 1608-1620. [CrossRef] [PubMed]

184. Sharma, R.; Liang, Y.; Lee, M.Y.; Pidatala, V.R.; Mortimer, J.C.; Scheller, H.V. Agrobacterium-mediated transient transformation of sorghum leaves for accelerating functional genomics and genome editing studies. BMC Res. Notes 2020, 13, 116. [CrossRef]

185. Li, J.F.; Norville, J.; Aach, J.; McCormack, M.; Zhang, D.; Bush, J.; Church, G.M.; Sheen, J. Multiplex and homologous recombination-mediated genome editing in Arabidopsis and Nicotiana benthamiana using guide RNA and Cas9. Nat. Biotechnol. 2013, 31, 688-691. [CrossRef]

186. Jiang, W.; Zhou, H.; Bi, H.; Fromm, M.; Yang, B.; Weeks, D.P. Demonstration of CRISPR/Cas9/sgRNA-mediated targeted gene modification in Arabidopsis, tobacco, sorghum and rice. Nucleic Acids Res. 2013, 41, e188. [CrossRef] [PubMed]

187. Nekrasov, V.; Staskawicz, B.; Weigel, D.; Jones, J.D.G.; Kamoun, S. Targeted mutagenesis in the model plant Nicotiana benthamiana using Cas9 RNA-guided endonuclease. Nat. Biotechnol. 2013, 31, 691-693. [CrossRef]

188. Upadhyay, S.K.; Kumar, J.; Alok, A.; Tuli, R. RNA-guided genome editing for target gene mutations in wheat. G3 2013, 3 , 2233-2238. [CrossRef] [PubMed]

189. Piatek, A.; Ali, Z.; Baazim, H.; Li, L.; Abulfaraj, A.; Al-Shareef, S.; Aouida, M.; Mahfouz, M.M. RNA-guided transcriptional regulation in planta via synthetic dCas9-based transcription factors. Plant Biotechnol. J. 2015, 13, 578-589. [CrossRef] [PubMed]

190. Yin, K.; Han, T.; Liu, G.; Chen, T.; Wang, Y.; Yu, A.Y.L.; Liu, Y. A geminivirus-based guide RNA delivery system for CRISPR/Cas9 mediated plant genome editing. Sci. Rep. 2015, 5, 14926. [CrossRef] [PubMed]

191. Schmitz, D.J.; Ali, Z.; Wang, C.; Aljedaani, F.; Hooykaas, P.J.J.; Mahfouz, M.; de Pater, S. CRISPR/Cas9 Mutagenesis by translocation of Cas9 protein into plant cells via the Agrobacterium Type IV secretion system. Front. Genome Ed. 2020, 2, 6. [CrossRef]

192. Baltes, N.J.; Hummel, A.W.; Konecna, E.; Cegan, R.; Bruns, A.N.; Bisaro, D.M.; Voytas, D.F. Conferring resistance to geminiviruses with the CRISPR-Cas prokaryotic immune system. Nat. Plants 2015, 1, 1-4. [CrossRef]

193. Vazquez-Vilar, M.; Bernabé-Orts, J.M.; Fernandez-del-Carmen, A.; Ziarsolo, P.; Blanca, J.; Granell, A.; Orzaez, D. A modular toolbox for gRNA-Cas9 genome engineering in plants based on the GoldenBraid standard. Plant Methods 2016, 12, 10. [CrossRef]

194. Ali, Z.; Abul-faraj, A.; Li, L.; Ghosh, N.; Piatek, M.; Mahjoub, A.; Aouida, M.; Piatek, A.; Baltes, N.J.; Voytas, D.F.; et al. Efficient virus-mediated genome editing in plants using the CRISPR/Cas9 system. Mol. Plant 2015, 8, 1288-1291. [CrossRef]

195. Alagoz, Y.; Gurkok, T.; Zhang, B.; Unver, T. Manipulating the biosynthesis of bioactive compound alkaloids for next-generation metabolic engineering in opium poppy using CRISPR-Cas9 genome editing technology. Sci. Rep. 2016, 6, 30910. [CrossRef]

196. Mubarik, M.S.; Khan, S.H.; Ahmad, A.; Khan, Z.; Sajjad, M.; Khan, I.A. Disruption of phytoene desaturase gene using transient expression of Cas9: gRNA Complex. Int. J. Agric. Biol. 2016, 18. [CrossRef]

197. Jia, H.; Wang, N. Targeted genome editing of sweet orange using Cas9/sgRNA. PLoS ONE 2014, 9, e93806. [CrossRef]

198. Jia, H.; Zhang, Y.; Orbovic, V.; Xu, J.; White, F.; Jones, J.; Wang, N. Genome editing of the disease susceptibility gene CsLOB1 in citrus confers resistance to citrus canker. Plant Biotechnol. J. 2016, 15, 817-823. [CrossRef]

199. Martín-Pizarro, C.; Triviño, J.C.; Posé, D. Functional analysis of the TM6 MADS-box gene in the octoploid strawberry by CRISPR/Cas9-directed mutagenesis. J. Exp. Bot. 2019, 70, 885-895. [CrossRef] [PubMed]

200. Stajič, E.; Kiełkowska, A.; Murovec, J.; Bohanec, B. Deep sequencing analysis of CRISPR/Cas9 induced mutations by two delivery methods in target model genes and the CENH3 region of red cabbage (Brassica oleracea var. capitata f. rubra). Plant Cell Tissue Organ Cult. 2019, 139, 227-235. [CrossRef]

201. Syombua, E.D.; Zhang, Z.; Tripathi, J.N. A CRISPR/Cas9-based genome-editing system for yam (Dioscorea spp.). Plant Biotechnol. J. 2020, 19, 645-647. [CrossRef] [PubMed]

202. Chen, K.; Gao, C. Targeted genome modification technologies and their applications in crop improvements. Plant Cell Rep. 2014, 33, 575-583. [CrossRef] [PubMed]

203. Bortesi, L.; Fischer, R. The CRISPR/Cas9 system for plant genome editing and beyond. Biotechnol. Adv. 2015, 33, 41-52. [CrossRef]

204. Goodin, M.M.; Dietzgen, R.G.; Schichnes, D.; Ruzin, S.; Jackson, A.O. pGD vectors: Versatile tools for the expression of green and red fluorescent protein fusions in agroinfiltrated plant leaves. Plant J. 2002, 31, 375-383. [CrossRef]

205. Jia, H.; Wang, N. Xcc-facilitated agroinfiltration of citrus leaves: A tool for rapid functional analysis of transgenes in citrus leaves. Plant Cell Rep. 2014, 33, 1993-2001. [CrossRef]

206. Poles, L.; Licciardello, C.; Distefano, G.; Nicolosi, E.; Gentile, A.; Malfa, S.L. Recent advances of in vitro culture for the application of new breeding techniques in citrus. Plants 2020, 9, 938. [CrossRef]

207. Li, X.; Li, H.; Zhao, Y.; Zong, P.; Zhan, Z.; Piao, Z. Establishment of Agrobacterium-mediated genetic transformation and application of CRISPR/Cas9 gene editing system to Chinese cabbage (Brassica rapa L. ssp. pekinensis). Res. Square 2020. [CrossRef]

208. Grefen, C.; Donald, N.; Hashimoto, K.; Kudla, J.; Schumacher, K.; Blatt, M.R. A ubiquitin-10 promoter-based vector set for fluorescent protein tagging facilitates temporal stability and native protein distribution in transient and stable expression studies. Plant J. 2010, 64, 355-365. [CrossRef]

209. Picard, K.; Lee, R.; Hellens, R.; Macknight, R. Transient gene expression in Medicago truncatula leaves via agroinfiltration. In Legume Genomics Methods Protocols; Rose, J.R., Ed.; Humana Press: Totowa, NJ, USA, 2013; pp. 215-226.

210. Lombardi, R.; Villani, M.E.; Di Carli, M.; Brunetti, P.; Benvenuto, E.; Donini, M. Optimisation of the purification process of a tumour-targeting antibody produced in N. benthamiana using vacuum-agroinfiltration. Transgenic Res. 2010, 19, $1083-1097$. [CrossRef] [PubMed] 
211. D’Aoust, M.A.; Lavoie, P.O.; Belles-Isles, J.; Bechtold, N.; Martel, M.; Vézina, L.P. Transient expression of antibodies in plants using syringe agroinfiltration. Methods Mol. Biol. 2009, 483, 41-50. [PubMed]

212. Du, J.; Rietman, H.; Vleeshouwers, V.G.A.A. Agroinfiltration and PVX agroinfection in potato and Nicotiana benthamiana. J. Visual Exp. 2013, 83, e50971. [CrossRef] [PubMed]

213. Schöb, H.; Kunz, C.; Meins, J.F. Silencing of transgenes introduced into leaves by agroinfiltration: A simple, rapid method for investigating sequence requirements for gene silencing. Mol. Gen. Genet. 1997, 256, 581-585. [CrossRef]

214. Voinnet, O.; Baulcombe, D. Systemic signalling in gene silencing. Nature 1997, 389, 553. [CrossRef]

215. Voinnet, O.; Vain, P.; Angell, S.; Baulcombe, D.C. Systemic spread of sequence-specific transgene RNA degradation in plants is initiated by localized introduction of ectopic promoterless DNA. Cell 1998, 95, 177-187. [CrossRef]

216. Bertazzon, N.; Raiola, A.; Castiglioni, C.; Gardiman, M.; Angelini, E.; Borgo, M.; Ferrari, S. Transient silencing of the grapevine gene VvPGIP1 by agroinfiltration with a construct for RNA interference. Plant Cell Rep. 2012, 31, 133-143. [CrossRef]

217. Dubey, V.K.; Lee, U.G.; Kwon, D.H.; Lee, S.H. Agroinfiltration-based expression of hairpin RNA in soybean plants for RNA interference against Tetranychus urticae. Pestic. Biochem. Physiol. 2017, 142, 53-58. [CrossRef]

218. Abbink, T.E.M.; Tjernberg, P.A.; Bol, J.F.; Linthorst, H.J.M. Tobacco mosaic virus helicase domain induces necrosis in N genecarrying tobacco in the absence of virus replication. Mol. Plant Microbe Interact. 1998, 11, 1242-1246. [CrossRef]

219. Palanichelvam, K.; Cole, A.B.; Shababi, M.; Schoelz, J.E. Agroinfiltration of cauliflower mosaic virus gene vi elicits hypersensitive response in Nicotiana species. Mol. Plant Microbe Interact. 2000, 13, 1275-1279. [CrossRef] [PubMed]

220. Van der Hoorn, R.A.L.; Laurent, F.; Roth, R.; De Wit, P.J.G.M. Agroinfiltration is a versatile tool that facilitates comparative analyses of Avr9/Cf-9-induced and Avr4/Cf-4-induced necrosis. Mol. Plant-Microbe Interact. 2000, 13, 439-446. [CrossRef]

221. Bendahmane, M.; Lynch, C., II; Tulsiani, D.R. Calmodulin signals capacitation and triggers the agonist-induced acrosome reaction in mouse spermatozoa. Arch. Biochem Biophys. 2001, 390, 1-8. [CrossRef] [PubMed]

222. Peart, J.R.; Lu, R.; Sadanandom, A.; Malcuit, I.; Moffett, P.; Brice, D.C.; Schauser, L.; Jaggard, D.A.W.; Xiao, S.; Coleman, M.J.; et al. Ubiquitin ligase-associated protein SGT1 is required for host and nonhost disease resistance in plants. Proc. Natl. Acad. Sci. USA 2002, 99, 10865-10869. [CrossRef] [PubMed]

223. Leckie, B.M.; Stewart, C.N. Agroinfiltration as a technique for rapid assays for evaluating candidate insect resistance transgenes in plants. Plant Cell Rep. 2011, 30, 325-334. [CrossRef]

224. Yang, Y.; Li, R.; Qi, M. In vivo analysis of plant promoters and transcription factors by agroinfiltration of tobacco leaves. Plant J. 2000, 22, 543-551. [CrossRef] [PubMed]

225. Rancé, I.; Norre, F.; Gruber, V.; Theisen, M. Combination of viral promoter sequences to generate highly active promoters for heterologous therapeutic protein over-expression in plants. Plant Sci. 2002, 162, 833-842. [CrossRef]

226. Merle, C.; Perret, S.; Lacour, T.; Jonval, V.; Hudaverdian, S.; Garrone, R.; Ruggiero, F.; Theisen, M. Hydroxylated human homotrimeric collagen I in Agrobacterium tumefaciens-mediated transient expression and in transgenic tobacco plant. FEBS Lett. 2002, 515, 114-118. [CrossRef]

227. Tampakaki, A.P.; Panopoulos, N.J. Elicitation of hypersensitive cell death by extracellularly targeted HrpZ $Z_{\text {Psph }}$ produced In Planta. Mol. Plant Microbe Interact. 2000, 13, 1366-1374. [CrossRef] [PubMed]

228. Vaquero, C.; Sack, M.; Schuster, F. A carcinoembryonic antigen-specific diabody produced in tobacco. FASEB J. 2002, 16, 408-410. [CrossRef] [PubMed]

229. Kathuria, S.; Sriraman, R.; Nath, R.; Sack, M.; Pal, R.; Artsaenko, O.; Talwar, G.P.; Fischer, R.; Finnern, R. Efficacy of plant-produced recombinant antibodies against HCG. Hum. Reprod. 2002, 17, 2054-2061. [CrossRef]

230. Vézina, L.P.; Faye, L.; Lerouge, P.; D’Aoust, M.-A.; Marquet-Blouin, E.; Burel, C.; Lavoie, P.-O.; Bardor, M.; Gomord, V. Transient co-expression for fast and high-yield production of antibodies with human-like N-glycans in plants. Plant Biotechnol. J. 2009, 7, 442-455. [CrossRef]

231. Habibi-Pirkoohi, M.; Malekzadeh-Shafaroudi, S.; Marashi, H.; Moshtaghi, N.; Nassiri, M.; Zibaee, S. Transient expression of foot and mouth disease virus (FMDV) coat protein in tobacco (Nicotiana tabacom) via agroinfiltration. Iranian J. Biotechnol. 2014, 12, 28-34. [CrossRef]

232. Liu, L.; Zhang, Y.; Tang, S.; Zhao, Q.; Zhang, Z.; Zhang, H.; Dong, L.; Guo, H.; Xie, Q. An efficient system to detect protein ubiquitination by agroinfiltration in Nicotiana benthamiana. Plant J. 2010, 61, 893-903. [CrossRef]

233. Pillay, P.; Kunert, K.J.; van Wyk, S.; Makgopa, M.E.; Cullis, C.A.; Vorster, B.J. Agroinfiltration contributes to VP1 recombinant protein degradation. Bioengineered 2016, 7, 459-477. [CrossRef]

234. Liu, W.; Mazarei, M.; Rudis, M.R.; Fethe, M.H.; Stewart, J.C.N. Rapid in vivo analysis of synthetic promoters for plant pathogen phytosensing. BMC Biotechnol. 2011, 11, 108. [CrossRef]

235. D'Aoust, M.A.; Lavoie, P.O.; Couture, M.M.-J.; Trépanier, S.; Guay, J.-M.; Dargis, M.; Mongrand, S.; Landry, N.; Ward, B.J.; Vézina, L.-P. Influenza virus-like particles produced by transient expression in Nicotiana benthamiana induce a protective immune response against a lethal viral challenge in mice. Plant Biotechnol. J. 2008, 6, 930-940. [CrossRef]

236. Rajabi, A.; Fahmideh, L.; Keikhasaber, M.; Omran, V.G. Evaluation of transient expression of $A S 1$ and $4^{\prime} C G T$ genes in African violets petals by agroinfiltration for production new color in the flower. Iranian J. Biol. 2021, 2021, $2383-2738$.

237. Liu, P.; Wang, Y.; Ulrich, R.G.; Simmons, C.W.; VanderGheynst, J.S.; Gallo, R.L.; Huang, C.-M. Leaf-Encapsulated vaccines: Agroinfiltration and transient expression of the antigen staphylococcal endotoxin B in radish leaves. J. Immunol. Res. 2018, 2018, 3710961. [CrossRef] 
238. Kaushik, P. Standardisation of an agroinfiltration protocol for eggplant fruits and proving its usefulness by over-expressing the SmHQT gene. Preprints 2019. [CrossRef]

239. Hesami, M.; Alizadeh, M.; Naderi, R.; Tohidfar, M. Forecasting and optimizing Agrobacterium-mediated genetic transformation via ensemble model- fruit fly optimization algorithm: A data mining approach using chrysanthemum databases. PLOS ONE 2020, 15, e0239901. [CrossRef] [PubMed]

240. Leuzinger, K.; Dent, M.; Hurtado, J.; Stahnke, J.; Lai, H.; Zhou, X.; Chen, Q. Efficient agroinfiltration of plants for high-level transient expression of recombinant proteins. J. Vis. Exp. 2013, 77, 50521. [CrossRef] [PubMed]

241. Mirakhorli, N.; Reyhani, A.H.; Shiran, B.; Hooshmand, S. Optimization of transient expression by Agrobacterium in almond. J. Genet. Eng. Biotechnol. 2014, 3, 9-18.

242. Kumar, S. Biosafety and Biosecurity Issues in Biotechnology Research. Biosafety 2015, 4, 1. [CrossRef]

243. Breyer, D.; Kopertekh, L.; Reheul, D. Alternatives to antibiotic resistance marker genes for in vitro selection of genetically modified plants-Scientific developments, current use, operational access and biosafety considerations. Crit. Rev. Plant Sci. 2014, 33, 286-330. [CrossRef]

244. Shanmugaraj, B.; Ramalingam, S. Plant expression platform for the production of recombinant pharmaceutical proteins. Austin J. Biotechnol. Bioeng. 2014, 1, 4 .

245. Mahesh, S. The state of art of new transgenic techniques in plant breeding: A review. J. Adv. Biol. Biotechnol. 2016, 9, 1-11. [CrossRef]

246. Grosse-Holz, F.; Madeira, L.; Zahid, M.A.; Songer, M.; Kourelis, J.; Fesenko, M.; Ninck, S.; Kaschani, F.; Kaiser, M.; van der Hoorn, R.A.L. Three unrelated protease inhibitors enhance accumulation of pharmaceutical recombinant proteins in Nicotiana benthamiana. Plant Biotechnol. J. 2018, 16, 1797-1810. [CrossRef] 